NBER WORKING PAPER SERIES

\title{
HAPPINESS ON TAP: PIPED WATER ADOPTION IN URBAN MOROCCO
}

\author{
Florencia Devoto \\ Esther Duflo \\ Pascaline Dupas \\ William Pariente \\ Vincent Pons \\ Working Paper 16933 \\ http://www.nber.org/papers/w16933
NATIONAL BUREAU OF ECONOMIC RESEARCH
1050 Massachusetts Avenue
Cambridge, MA 02138
April 2011

We are grateful to Olivier Gilbert, from Veolia Environnement, for numerous helpful discussions, and seminar participants at Harvard/MIT, RAND, IADB, USC and UC Louvain for useful comments. We thank the entire team at Amendis for their generous collaboration and Diva Dhar for excellent research assistance. We gratefully acknowledge funding from Veolia Environnement, and disclose that Amendis is a wholly owned subsidiary of Veolia Environnement. However, Veolia Environnement did not influence the research design, the conduct of the research, or the write-up of this paper. The views expressed herein are those of the authors and do not necessarily reflect the views of the National Bureau of Economic Research.

NBER working papers are circulated for discussion and comment purposes. They have not been peerreviewed or been subject to the review by the NBER Board of Directors that accompanies official NBER publications.

(C) 2011 by Florencia Devoto, Esther Duflo, Pascaline Dupas, William Pariente, and Vincent Pons. All rights reserved. Short sections of text, not to exceed two paragraphs, may be quoted without explicit permission provided that full credit, including $\odot$ notice, is given to the source. 
Happiness on Tap: Piped Water Adoption in Urban Morocco

Florencia Devoto, Esther Duflo, Pascaline Dupas, William Pariente, and Vincent Pons

NBER Working Paper No. 16933

April 2011

JEL No. D12,I38,O12

\begin{abstract}
We study the demand for household water connections in urban Morocco, and the effect of such connections on household welfare. In the northern city of Tangiers, among homeowners without a private connection to the city's water grid, a random subset was offered a simplified procedure to purchase a household connection on credit (at a zero percent interest rate). Take-up was high, at 69\%. Because all households in our sample had access to the water grid through free public taps (often located fairly close to their homes), household connections did not lead to any improvement in the quality of the water households consumed; and despite significant increase in the quantity of water consumed, we find no change in the incidence of waterborne illnesses. Nevertheless, we find that households are willing to pay a substantial amount of money to have a private tap at home. Being connected generates important time gains, which are used for leisure and social activities, rather than productive activities. Because water is often a source of tension between households, household connections improve social integration and reduce conflict. Overall, within 6 months, self-reported well-being improved substantially among households in the treatment group, despite the financial cost of the connection. Our results suggest that facilitating access to credit for households to finance lump sum quality-of-life investments can significantly increase welfare, even if those investments do not result in income or health gains.
\end{abstract}

Florencia Devoto

Paris School of Economics

48 boulevard Jourdan

75014 Paris France

fdevoto@povertyactionlab.org

Esther Duflo

Department of Economics

MIT, E52-252G

50 Memorial Drive

Cambridge, MA 02142

and NBER

eduflo@mit.edu

Pascaline Dupas

Department of Economics

UCLA

8283 Bunche Hall

Los Angeles, CA 90095

and NBER

pdupas@econ.ucla.edu
William Pariente

Institut de Recherche Économique et Sociale (IRES)

Universite Catholique de Louvain

Place Montesquieu 3, B-1348

Louvain-la-Neuve, Belgium

william.pariente@uclouvain.be

Vincent Pons

MIT Department of Economics

50 Memorial Drive

Cambridge, MA 02142

vpons@mit.edu 


\section{Introduction}

Worldwide, 1.1 billion people have no access to any type of improved drinking source of water within 1 kilometer. Furthermore, only about 42 per cent of the people with access to water have a household connection or yard tap (WHO/UNICEF, 2005). As a result, households in developing countries spend considerable amount of time fetching water. For example, Kremer et al. (2010) estimate that a rural household in Western Kenya does around seven water-fetching trips per day, with each trip requiring a 20-minute walk on average. In urban Morocco, the setting of this study, households that rely on public taps spend more than seven hours a week collecting water, despite the higher density of water taps. The time-burden of water collection does not typically spare anyone in the household, but in many countries it is borne primarily by women and girls. This burden generates considerable stress and tension. For example, in Morocco, 66\% of households without a water connection report that water is a major source of concern; $16 \%$ have had a water-related conflict within the family; and $12 \%$ have had water-related conflict with their neighbors.

The prime objective of connecting poor households to the drinking water network is usually to improve their physical health. Yet, over and beyond its direct effect on physical health, improved water access could have important effects on household well-being. By reducing the time burden of water collection, it not only frees up time that could be spent on additional leisure or production, it also removes an important source of stress and tension. On the other hand, if women face restricted mobility besides their daily trips to the public water source, a home water connection could cut off an important source of opportunities to socialize, and possibly reduce their well-being.

The first order effects of access to clean water on health, even in cities, have been amply demonstrated (Merrick, 1985; Galiani, Gertler and Schardrogsky, 2005; and Gamper-Rabindran, Khan and Timmins, 2010). Given these first-order effects, it is difficult, in most settings, to separate the effects of clean water due to the reduced burden of water collection from the effects due to health. This paper uses a randomized design to study the non-health effects of easier access to in-home water connections on poor urban households in Morocco. Because households in our sample already had access to clean water from a public tap, household connections did not 
lead to improvements in water quality, allowing us to identify the specific effect of a reduced water-collection burden on time use, social integration, and mental well-being. We find considerable improvement in all these dimensions, without any change in the incidence of waterborne diseases (despite an apparent increase in the quantity of water consumed). This suggests that the time and resources spent on water collection substantially reduce welfare of poor households, a finding consistent with their high willingness to pay for a household connection.

We worked in collaboration with Amendis, the local affiliate of Veolia Environnement, an international private utility company, which operates the electrical and wastewater collection networks as well as the drinking water distribution in Tangiers, Morocco. In 2007, Amendis launched a social program to increase household direct access to piped water. As of the end of 2007, approximately 845 low-income households living in "on-the-grid neighborhoods" of Tangiers (i.e. in principle easily connectable) did not have a household water connection because they could not afford the connection fee. Before getting a connection, all these households had free access to public taps installed in their neighborhood, and they had access to sanitation at their house. The Amendis program provided an interest-free loan to cover the cost of the water connection (which was not subsidized, on average). The loan was to be repaid in regular installments with the water bill over three to seven years. We implemented an encouragement design at the start of the program: we conducted a door-to-door awareness and facilitation campaign in early 2008 among 434 households, randomly chosen from the 845 that were eligible for a connection on credit. Those households received information about the credit offer as well as help with the administrative procedures needed to apply for the credit and the water connection: specifically, all the necessary paperwork was photographed in their house, and brought to the municipal office for bulk approval. The remaining households (the comparison group) were eligible to apply for a connection on credit if they wanted to ( $10 \%$ of them did), but they received neither individualized information nor procedural assistance.

The information and facilitation drive was very successful: by August 2008 (6 months after the start of the information campaign), $69 \%$ of households in the treatment group had purchased a connection (against 10\% in the control group), and as a result their average monthly water bill 
doubled, from 78 to 147 Moroccan dirhams (MAD), or US\$11 to $\$ 21$ a month. ${ }^{3,4}$ The quality of water was unchanged since public taps are also maintained by Amendis and the water flowing into public or private taps comes from the same source. There was, however, a large increase in the quantity of water consumed, which some have argued could be as important for health as water quality (Esrey et al., 1991). Despite this change in water quantity, we find no change in the incidence of waterborne diseases, such as child diarrhea. This confirms the meta-analysis of Fewtrel and Colford (2004), arguing that water quantity may not, after all, matter for child health.

In contrast, the connection generated important time gains. These time gains did not lead to increases in labor market participation, income, or schooling attainment. Rather, the spared time was used for leisure and socializing. The private connection reduced the risk of conflict or illfeelings between neighbors. Overall, despite the financial cost, we observe that households' reported well-being improves substantially when they get connected to the water system. These results echo those of Cattaneo et al. (2009), showing that a program in Mexico replacing dirt floors with cement floors significantly improved adult welfare, as measured by increased satisfaction with their housing and quality of life. However, Cattaneo et al. (2009) find that cement floors also improve child health, and they hypothesize that that may be a source of the increase in happiness.

Given the important change in well-being we observe among households in the treatment group, it is quite striking that the simple "nudge" of providing information and facilitating administrative procedures had such a large effect on the take-up of the credit offer from Amendis. This could be due either to a lack of information (the credit program was not discussed in the media nor discussed at town hall meetings), or to the fact that households on their own were not able to surmount the quite formidable administrative barriers imposed by the program. A natural question is thus whether the experience of households in the treatment group encouraged their neighbors or social contacts to also invest in a household connection. By August 2009 (18 months after the awareness campaign had taken place among treatment households), the fraction of control households that had applied for a connection had risen to $27 \%$ (from $10 \%$ a year earlier). To test whether this rise can be attributed to social diffusion

\footnotetext{
${ }^{3}$ The exchange rate at the time of the study was approximately 7 MAD to US\$1.

${ }^{4}$ The cost at baseline was non-zero because some households were purchasing water from their neighbors.
} 
effects, we exploit the random variation in the density of households sampled for the encouragement treatment. Among control households that had at least one other study household within 20 meters of their house, holding the number of study households within that radius constant, we find that those who had at least one treatment household within 20 meters were 18 percentage points more likely to have bought a water connection by August 2009 than those who did not have any treatment households within 20 meters. This difference is significant at the 5\% level, and suggests important social diffusion effects.

Overall, our results suggest that, at least in the Moroccan context, households have a relatively large willingness to pay for the convenience of a water connection at home. This is particularly interesting in light of recent evidence from randomized experiments in Zambia (Ashraf et al, 2010) and Kenya (Kremer et al, 2009, 2010) suggesting that the willingness to pay for water quality (in terms of money spent on chlorine or extra time spent collecting water) is relatively low. In contrast, households seem to be willing to pay a lot for quantity and ease of access.

To our knowledge, this paper provides the first experimental estimates of the effect of providing households with the option to connect to the piped water system in a setting where public taps with good water quality exist, in contrast with only providing public taps, arguably a cheaper way to ensure everyone has access to safe drinking water. Improving access to safe drinking water and basic sanitation is one of the Millennium Development Goals, and accordingly, many initiatives in the developing world, such as the "National Initiative for Human Development" in Morocco, are planning or are in the process of increasing access to safe drinking water by helping poor households get connected to piped water. Our results suggest that such initiatives, while they may not improve child health, can have substantial welfare effects at relatively low marginal public cost, since households are willing to pay for the extra cost of the connection to the grid. Our findings also suggest that access to credit, rather than costs, may be a significant barrier to improvement in household infrastructure. Overall, our results suggest that access to credit can enable households to invest in lump-sum quality-of-life investments that can significantly improve welfare, even if they do not result in income gain. ${ }^{5}$ Finally, the contrast between the willingness to pay the water bills and the large increase in life satisfaction for households who got a connection on the one hand, and the important effects on take-up of a

\footnotetext{
${ }^{5}$ This finding is consistent with that of Banerjee, Duflo, Glennerster and Kinnan (2010), who find that, in India, households use microcredit loans to purchase assets for their homes more often than to start a new business.
} 
campaign that simply reduced informational and administrative barriers on the other hand, is quite striking. It underscores the power of the status quo and the potentially high returns of designing programs with simplicity and ease of access in mind, even when they are expected to have high benefits.

\section{Research Design}

\subsection{Amendis's BSI program}

Amendis is a public-private partnership (a wholly owned subsidiary of Veolia Environnement) responsible for the management and operation of public services such as potable water, sanitation and electricity distribution networks in the city of Tangiers.

One of Amendis's mandates is to increase access of low-income households to basic infrastructure. As such, Amendis created a program called “Social Home Connections” (in French, "Branchements Sociaux Individuels" or BSI), which allows low-income households to buy a connection to the water and sanitation network at full cost, but on credit. The price of a connection is a function of the works required to install a pipe from the network to the home entrance. Households in the inner city face one of three prices, depending on their distance from the grid: the zone 1 price is 3,790 MAD (around US\$540), the zone 2 price is 6630 MAD (\$940) and the zone 3 price is 9,370 $\mathrm{MAD}(\$ 1,340)$. All three price categories represent relatively important lump sums that many households without access to formal credit can probably not pay upfront. The BSI program offered interest-free credit to households in Tangiers' inner city interested in getting a connection. Households have to repay the credit over a period of 3, 5 or 7 years (depending on the price they faced for the connection) at a monthly rate of 105 MAD or $\$ 15$.

\subsection{Sampling Frame}

Using detailed maps of the city of Tangiers, and merging them with information on existing water connections registered in the Amendis database, we first identified 4,600 "plots" that did not seem connected to the city water system but that fell within the three zones that Amendis had delineated for the BSI program. A team of surveyors we hired inspected these plots and carried 
out a quick survey to estimate their eligibility for the program. Eligibility required that (1) the plot was indeed not already connected to a water network (12\% of plots did not meet this criteria, due to flaws in the Amendis database); (2) the plot was used for residential purposes (25\% plots were excluded because they were empty, and 14\% were excluded because they were used for commercial purposes); (3) the plot hosted the main residence of at least one owner or non-paying family occupant (20\% of plots were excluded because they were occupied by tenants).

Our final sample includes 845 households residing on 732 plots. These plots host relatively small houses, with a surface below 100 square meters for $96 \%$ of the houses. Most plots were inhabited by only one household (79\% of plots), but $15 \%$ included two households, and 6\% of plots included three or more households. Close to $60 \%$ of households relied on the public tap as their main source of water (Table 1). The rest were getting their water from a neighbor (either directly through a hose or by filling containers), in which case they typically shared the water bill with them. These "informal" connections are called "piquage” and are illegal, but tolerated. We discuss these baseline characteristics in more detail in section 3.3.

\subsection{Experimental Design}

The experiment relied on an encouragement design. Households in the sample were randomly assigned to a "treatment" and a “control” group. The "treatment” consisted of an information and marketing campaign about the BSI program, along with assistance in preparing the application. The three main hurdles in the application process were the following: obtaining an authorization from the local authorities, providing photocopies of important identification documents, and making a down payment at the branch office. We simplified these procedures radically for households in the treatment group, by obtaining pre-approval from the authorities in bulk, making digital copies of their identification document at home (with cameras), and bringing a branch officer to their home to collect the payment. Thus, control households could have obtained a connection (some did), but they would have to be aware of the new program and manage all the paperwork, while treatment households were individually informed and helped.

Since part of the strategy relied on differential access to information, in order to avoid assigning immediate neighbors to different groups, the assignment of households to the treatment and control groups was done after clustering by location. But we also wanted to be able to test for the 
presence of "post-connection” spillovers, e.g. to test whether non-connected households who interact with newly connected households are more likely to apply for a connection. For this reason, the randomization was done at an intermediate cluster level: neither at the household level, nor at the water source level, but at what we call the "block level".

Specifically, the 732 plots in the sample were grouped into blocks, or "clusters", as follows: two adjacent plots, or two plots facing each other on the street or up to one house apart, were considered part of the same cluster. In total, this method generated 626 clusters. These clusters were then randomly assigned (by the research team) to one of the two groups: the treatment group (315 clusters, including 372 plots and 434 households) and the control group (311 clusters, including 360 plots and 411 households). These clusters are sufficiently close to each other that

the information can probably flow from one cluster to the next. In section 6.2 below, we study the diffusion of the information on the water connection to geographic neighbors who were not directly targeted by the intervention.

The random allocation of clusters between treatment and control groups was stratified by location, water source, the number of children under-five, and number of households within the cluster.

\section{Data}

\subsection{Data Collection}

\section{Baseline Household Survey}

A baseline survey was administered in August 2007. It included modules on socioeconomic characteristics, work and work-related conditions, health, hygiene practices, water collection, storage and treatment practices, social networks, as well as a time use survey for the female head and the main child in charge of fetching water. In addition, for a random subsample of households, the drinking water was tested for levels of chlorine and the presence of the fecal coliform bacteria $E$ coli. This test was performed in a laboratory. 
Incidence of illnesses: daily follow-up via « illness diaries »

We carried out an initial month-long survey in December 2007 to estimate the occurrence of illnesses among children (diarrhea, fever and vomiting). Data collection of this type requires multiple successive visits to the households in order to record an evolution in the occurrence of illnesses. We did this as follows. In each household, a first visit was made to distribute an "illness diary". The adult identified as the primary caretaker of the children (the mother in most of the cases) was asked to fill out the diary each day, and mark with crosses the occurrence of fever, vomiting or diarrhea attacks. The diary had been designed in such a way that even an illiterate person would be able to fill it out (a copy of the diary is presented in Appendix A). At the end of each of the 4 weeks during which the diary was filled, a surveyor visited the households to collect the week's information and discuss about illness episodes with the female head, and, if necessary, complete and correct the diary for that week. Note that, as these questions only concern children under the age of 15 years, the illness diaries were used only with the 437 households who had declared having children in this age bracket at the time of the initial survey.

Treatment and control households with children under the age of 15 years participated in a similar health monitoring scheme in the months of May, August and November 2008. During each of these three months, the households filled a new illness diary with the regular help of a surveyor. The diaries used were identical to the one used in the initial survey of December 2007 and the protocol used to monitor their use was the same as that used at baseline.

\section{Endline Household Survey}

A final survey, similar to the initial survey, was carried out in August 2008, 6 months after the information and marketing campaign, and on average, 5 months after the installation of household connections for the treatment group. (On average, households received the water connection 25 days after completing their BSI application.)

Among the 845 households who participated in the baseline survey, 793 households (94\%) could be resurveyed. Attrition was due to the following: around $2 \%$ of the baseline household had moved house, without leaving behind their new address. $2 \%$ refused to answer, despite repeated efforts made by the surveyors. The remaining $2 \%$ consisted of households who were absent (on vacation, Hajj pilgrimage, etc.), or households whose sole-member had passed away. 


\subsection{Data Quality Assurance}

To obtain truthful information from households and to avoid creating any desirability bias in the treatment group, the data collection efforts were completely separated from the BSI program implementation itself. Namely, the staff that conducted the information campaign and assisted households in the treatment group with their connection application was completely different from the team of enumerators that administered surveys. We obtained a waiver of informed consent from the relevant IRBs in order to not be obligated to disclose the full design of the study to the participants until the very end. ${ }^{6}$ This also enabled us to ensure that the survey team did not know about the research team's relationship with the BSI program.

\subsection{Verifying Randomization}

Table 1 presents summary statistics for households in the sample, separately for the control and treatment groups. We also show the difference between the means of the two groups and report the p-value of a test of the null hypothesis that they cannot be distinguished from each other.

Overall, households in the two groups are extremely similar. Out of 57 differences shown in Table 1, only 3 are significantly different from zero at the $10 \%$ level and only 2 are significant at the $5 \%$ level, as should be expected.

As mentioned above, at baseline just below $60 \%$ of households used the public tap as their main source of water. Of those, $22 \%$ (15\% of the total) lived sufficiently close to the public tap to use a hose to fill their water containers at home. The remainder (around $43 \%$ of our sample) had to take their containers to the public tap. On average, those households who carried containers to and back from the public tap lived 112 meters away from the closest public tap. At baseline, they reported filling 52 containers per week. The average time spent fetching water was around 7.2 hours per week for these households. Water collection trips are common among both men and women, but done mostly by adults: while households do more than 7 trips per 3-day period to the public tap, less than one of those trips is done by a child under 15 .

\footnotetext{
${ }^{6}$ At the end of the study, we fully informed all participants about the study, and asked them for informed consent to let us use the data collected from them over the previous two years. Participants in the control group were visited at their home in January 2009 and given full information about the BSI program.
} 


\section{The Demand for Private Taps: Take-up of the BSI credit offer}

Figure 1 presents summary statistics on the take-up of the BSI offer by group (Panel A) and by initial water source among those in the treatment group (Panel B). The randomized encouragement design had a very large effect on the probability of obtaining a water connection. By August 2008, 6 months after the initiation of the encouragement for the treatment group, 298 (68.7\%) of the 434 households in the treatment group had gotten connected to the water system. In contrast, only 40 out of 411 households in the control group (9.7\%) were connected.

Among households in the treatment group who did not get connected to the water system, the most commonly cited reasons for refusing the BSI offer were the following: inability to pay, especially for households with just one member, who was typically an elderly person; inheritance problems (i.e., no clear property rights over the house); and plans to move out.

We formally estimate the correlates of the demand for a household connection in Appendix Table A1. We present the results of a linear probability model regression, estimated on the treatment group only. The dependent variable is a dummy equal to 1 if the household bought the household connection. We control for geographic variables (longitude and latitude) and cluster the standard errors at the block level (the unit of randomization, as described above). Perhaps somewhat surprisingly, the price of the water connection had little effect on demand. Demand was actually highest in the highest price group (zone 3), and lowest in the second price group (zone 2), although the differences are insignificant. The number of households living on the plot also did not affect the demand, even though it typically implied a lower price (since some of the fixed construction costs were shared). This suggests that the underlying demand for a connection may have been quite high, and access to credit and/or administrative complexity were the barriers.

The other baseline characteristics have the expected sign. Households who relied on the public tap at baseline (by contrast to those who got water through a neighbor) were significantly more likely to take up the connection, and distance to the public tap significantly increased take-up. The number of water fetching trips in the past three days reported at baseline does not explain take-up, but the share of those trips done by children significantly increased the likelihood that households invested in a connection. Finally, larger households, who presumably have higher water needs, as well as richer households, were more likely to take-up the connection. 


\section{Short-run effects of improved water access}

\subsection{Empirical Strategy}

We estimate the effect of getting easier access to a household connection on a host of outcomes: quality and quantity of water consumed, water-related time and financial costs incurred by the household, child health, time use, social integration, and overall well-being. For each series of outcomes, we estimate two parameters of interest. First, we are interested in the effect of being assigned to the treatment group, examined for each outcome using the following specification:

$$
Y_{i}=\alpha_{1}+\beta_{1} \text { Treat }_{i}+X_{i}^{\prime} \delta_{1}+\varepsilon_{i 1}
$$

where $Y_{i}$ is the outcome of interest for household $i$, Treat $t_{i}$ is a dummy equal to 1 if the household has received the encouragement and $X_{i}$ is a vector of household characteristics. Randomized assignment of Treat $_{i}$ ensures that $E\left(\varepsilon_{i 1} \mid X_{i}\right.$, Treat $\left._{i}\right)=0$, and therefore OLS estimates of $\beta_{1}$ will be unbiased. We adjust the standard errors for clustering.

Secondly, we are interested in evaluating the average effect of actually having a household connection on each outcome. This is estimated with the following specification:

$$
Y_{i}=\alpha_{2}+\beta_{2} \text { Connected }_{i}+X_{i}^{\prime} \delta_{2}+\varepsilon_{i 2}
$$

where Connected $_{i}$ is a dummy variable equal to 1 if the household is connected to the water grid, and is instrumented with Treat $_{i}$ as follows :

$$
\text { Connected }_{i}=a+\text { breat }_{i}+v_{i}
$$

The estimation of this first stage equation is presented in the first column of Table 2.

In all tables that follow, we present estimates of equation (1) in Panel A, and estimates of equation (2) in Panel B. For brevity we only present results that include controls for household characteristics $\left(X_{i}\right)$, but the results remain essentially unchanged when such controls are omitted. ${ }^{7}$

In addition to estimating the average treatment effects, we also provide evidence of the treatment effects estimated separately for households that were truly unconnected at baseline, and

\footnotetext{
${ }^{7}$ The baseline household characteristics included as controls are: number of children under 15, quintile in asset distribution, water consumption, and distance to the public tap.
} 
households that were indirectly connected through an illegal pipe linked to their neighbor's tap. While households who already had running water through their neighbors had potential incentives to purchase a private connection through the BSI program, it is likely that the switch from an indirect to a direct connection had a lower impact on their lives than the switch from no running water to running water. ${ }^{8}$ To allow for such heterogeneity in the treatment effects by initial water source, we estimate the following equation:

$$
Y_{i}=\alpha_{3}+\beta_{3} \text { Treat }_{i}+\zeta_{3} N_{i}+\gamma_{3} \text { Treat }_{i} \times N_{i}+X_{i}^{\prime} \delta_{3}+\varepsilon_{i 3}
$$

where $N_{i}$ is a dummy variable equal to 1 if the household's main source of water at baseline was an illegal pipe linked to a neighbor connected to the grid. In this specification, $\beta_{3}$ estimates the impact of the treatment for those truly without running water at baseline, while the sum of the coefficients $\beta_{3}+\gamma_{3}$ estimates the impact of the treatment for those who already had running water at baseline (through their informal connection).

We present results on a wide array of outcomes. While we typically estimate impacts on each individual outcome through independent regressions, we also follow Kling, Liebman and Katz (2007) and construct summary indices that aggregate information over multiple treatment effect estimates, for given families of outcomes. For example, we create a child diarrhea index that averages the treatment effects estimated over the three waves of diarrhea data collected. Likewise, we create a mental health index that averages the treatment effects estimated over three measures of mental well-being. Specifically, we look at the average treatment effect where $\tau$ is the mean effect size over $\mathrm{K}$ outcomes, based on the treatment effect estimate $\beta_{k}$ on each outcome:

$$
\tau=\frac{1}{K} \sum_{k=1}^{K} \beta_{k}
$$

We estimate the standard error of $\tau$ using seemingly unrelated regressions, in order to account for the covariance in the treatment effects.

\footnotetext{
${ }^{8}$ Given Amendis's water pricing scheme (which includes consumption brackets), the average cost per cubic meter could potentially go down for households that stopped sharing a meter with their neighbor and instead acquired their private connection. The availability of the BSI program also reduced the potential "monopoly" pricing power of connected neighbors. Finally, water is often a source of tension between neighbors. Buying one's private connection might have been a way to buy peace with one’s neighbors.
} 


\subsection{Quality and Quantity of Water Used}

The impact of the BSI offer on the quality and quantity of water used is analyzed in Table 2 . We find no effect of getting connected to the water system on the main indicator of the quality of drinking water, the level of fecal bacteria E coli detected (column 3) even though there is a 15 percentage points increase in the likelihood that chlorine was detected in the drinking water of treatment households (column 5). These results suggest that the quality of water coming from public taps is relatively high (though not perfect, since the $E$ coli count is around 10 on average, and not zero as recommended), and that there is no further contamination during the transport of water carried home, or while the water is stored at home.

While there is no effect on the quality of drinking water, getting connected seems to lead to a substantial increase in the quantity of water available. Households in the treatment group are 20 percentage points more likely to report having enough water for bathing (the mean in the control group is 67\%) and 16 percentage points more likely to report having enough water for cleaning. The IV estimates suggest that water shortages are completely eliminated for households that get connected. Finally, respondents in the treatment group report increasing their frequency of baths and showers: the number of times respondents in the treatment group had a bath or shower at home during the last 7 days is $11 \%$ higher than in the control group $(0.30 / 2.75$, column 11$)$. Note that, unsurprisingly, all these effects are concentrated among households who did not have running water at baseline: the coefficients on the treatment effects for those who had an informal connection at baseline (row 3) have the same magnitude but the opposite sign as those of the main treatment effects (row 1), which implies that the total treatment effects for those households already connected was essentially zero.

\subsection{Costs}

Table 3 estimates the impact of the BSI offer on the time and financial costs experienced by households. Overall, we find that household connections generate a substantial time gain for their beneficiaries, but at the same time generate a substantial financial cost since households now have to pay for their water as well as repay the BSI credit.

Columns 1 to 8 of Table 3 show that the connection considerably reduced the number of water fetching trips in the treatment group. The time the household spent fetching water in the last 3 days reduced from 82 minutes on average in the control group, to essentially zero. This effect is 
entirely concentrated among those who did not have running water to start with - reassuringly, the effect for those with an informal connection at baseline is literally zero (the sum of the coefficients in row 1 and row 3 is close to zero for all these time outcomes).

The finding that trips to the public tap went down to zero for those initially relying on it is more interesting than it seems. Water at public taps is free, while households have to pay for the water that is piped directly to their home. Therefore one of the concerns at the time the BSI program was designed was that people would keep using the public tap and limit their private tap usage, in order to limit the size of their water bill. We find little supporting evidence for this.

The spared time comes at a cost. First, households had to pay a relatively large fixed cost to get connected (column 9 and 10). Second, once connected, households have to pay both their monthly water bill and their monthly installment. Overall, the IV estimates suggest that the average monthly water costs almost doubled for those who bought a connection, from 78 to around 147 MAD, a jump from US \$11 to \$21 (Table 3, columns 11-12). This increase corresponds to $2 \%$ of reported total household expenditures, and to $13 \%$ of declared labor income for the household. (Labor income is likely to be underreported in our sample, however.)

\subsection{Health}

The major result arising from the analysis of our health data is the absence of any systematic positive effect of the program on health of either children or adults. The data on the incidence of water-related illnesses (diarrhea, vomiting, and fever) collected through detailed illness diaries show no significant pattern. We present the results for diarrhea among children aged five or younger in Table 4. None of the coefficients are significant, and their sign changes from one wave of data to the next, suggesting no consistent pattern (Table 4). Overall, the point estimate for the average effect across all waves is close to zero, and we can reject at the $5 \%$ level a reduction of 16 percentage points (about half) in diarrhea incidence (column 10). The addition of various control variables does not change the results. The effects on diarrhea among older children, or on fever and vomiting, are similar (data not shown).

We collected data on two other water-related illnesses (skin and eye infections among adults and children, and digestive problems for adults), but also find no effect of the treatment on any of these, for any age group. We also do not find any effect when we look at the number of medical visits reported at endline (data not shown). 
The lack of effects on health is probably due to the fact that the households in our sample already had access to relatively good quality water as well as good access to sanitation. Most households reported using the Amendis sanitation system to discharge used water and 95\% reported having a toilet at home. Nevertheless, positive effects could have been expected from the improvement in quantity and the corresponding increase in the washing frequency of households' members (Esrey et al., 1991). The fact that we find no health effects despite the effect on quantity suggest that water quantity, alone, plays at best a small role in health, at least in the context studied (an urban area where households still had relatively easy access to water from a nearby public tap).

\subsection{Time Use}

As shown earlier, the connection generated large time gains for households who no longer needed to spend time fetching water. Five months after they got connected, these time gains were still very salient for households. Table 5 presents estimates of respondents' self-perception of time availability. When asked to compare their current situation with that a year before, respondents in the treatment group reported significantly more gains in time for daily activities such as housework and watching television than the control group (column 1 to 4). Respondents in the treatment group also reported having gained comparatively more time to engage in social activities, such as visiting or receiving the visits of family or friends (columns 5 to 12).

Table 6 presents estimates of the respondents' actual use of time. The effects are positive but not always significant. When we create an index of time spent on leisurely activities, using detailed time use data collected at endline, we find a positive and significant effect (columns 9 and 10). Somewhat surprisingly, the point estimate of the effect is larger for those illegally connected at baseline, but the difference is not statistically significant.

Table 7 presents results on two other time categories: labor market participation and schooling participation (for children). Data on labor market participation comes from the question: "Did this person engage in an income generating activity in the past 30 days?”, which was asked at endline to the main respondent (typically the female head of the household) about each household member. If the answer was yes, we then asked the income gained over the past 30 days. The data on school participation presented in columns 11-14 also comes from the endline: we know the share of children aged between 5 and 15 who completed the 2007/2008 school year 
(the endline was administered in the summer, between two academic years). We also collected detailed school absenteeism data through the use of diaries (similar to the health diaries).

Overall, the results are clear: the time gained with the water connection had no impact on productive activities. We find no increase in the probability that either male or female heads in treatment households participate in the labor market. As a result, the program had no effect on income (although our income data is extremely noisy and the standard errors are extremely large, even with trimming). While it is possible that the impact of time gains on productive activities might take more than 5 months to be effective and thus was not captured in our endline survey, we also cannot rule out the possibility that our labor market participation and income data suffer from under-reporting biases. While there is no reason to believe that the under-reporting bias would be correlated with the water connection itself, it has been shown that under-reporting of income increases as income goes up.

The analysis of the impacts on educational investments does not show any impact in time spent studying either. First, we find no effect on school participation as measured by school completion (Table 7, columns 11-12). Second, detailed school absenteeism data collected through the use of diaries show no impact on the intensive margin of schooling (data not shown). Finally, the time use data collected at endline for children of school age suggests no change in time spent doing homework. These results are not surprising since children were rarely involved in water fetching at baseline (only 1 trip every two weeks on average, as shown in Table 1), and since we find no health gains.

Overall, the results in this section suggest that households used the time saved for leisure only. What willingness-to-pay for leisure does that imply, and how does that compare with the local hourly wage? Assuming households in our sample discount the future at a reasonable rate, the estimates in Table 3 suggest that the water connection cost households around 12 MAD per hour saved. In comparison, the minimum wage for employees in Morocco is 9.6 MAD per hour. This is likely an upper bound on the average wage in our sample, since the great majority of individuals in our sample were either casual workers or unemployed. The fact that our estimated willingness-to-pay for leisure is somewhat higher than the hourly wage suggests that the benefits of the water connection likely went beyond the time saved. We know that there were no health benefits, however. What other benefits could the water connection have brought? In the next 
sections we study the impact of the connection on social integration and well-being. Consistent with the relatively high implied willingness-to-pay, we find positive impacts on these outcomes.

\subsection{Social Integration}

While getting a household connection might have reduced the opportunities to socialize while fetching water, the overall impact of the treatment on social integration seems to have been positive. Table 8 presents results on various measures of the strength of social ties. The first two columns suggest that the treatment increased the likelihood that households belong to a social group. While overall participation in social groups is very rare (only $2 \%$ of the control group report participating), it is twice as high in the treatment group. Interestingly, this effect is entirely driven by an increase in the likelihood that households belong to a rotating savings and credit association (ROSCA). This may be due to the fact that households get help from the ROSCA structure to pay the installments, or that having to pay their bill regularly generates a habit of regular contributions to a fund.

In addition, gaining access to a private water connection seems to ease the tensions that surround access to water. Tensions arise when people compete for access to a public tap, or share a private tap and need to divide water bills among relatives or neighbors. Even within the household, both the allocation of the task of fetching water and the allocation of the water at hand among possible uses can be a source of tension. And indeed, our data suggests that water is a common source of conflict: at endline, $16 \%$ of control households stated that they were in conflict or disagreement with family members on water-related problems (column 3), and 12\% were in disagreement with neighbors on such issues (column 9). These sources of tensions were almost completely eliminated as a result of the program, as shown in columns 3-4 and 9-10 of Table 8 . The ITT estimates show a $69 \%$ reduction in the proportion of households in conflict or disagreement with family members and neighbors on water-related problems, and the IV estimates suggest a complete elimination of such conflicts for those who got a connection. Note that treatment households are not less likely to report conflicts with respect to matters unrelated to the treatment (property or heritage issues, in columns 5-9 and 11-12), which suggests that it is indeed access to water that reduces water-related conflict. 


\subsection{Mental Well-Being}

Overall, households in the treatment group relative to the control group were much less likely to report feeling unhappy about their water situation. Table 9 presents estimates of the effects on several measures of satisfaction. While $66 \%$ of control households mentioned water when prompted to list their 5 major sources of concerns, only $28 \%$ of treatment households did so (column 1). This went down to zero among households that did get connected, as shown by the IV estimate in Panel B. Similarly, the proportion of households that mention that their house is cleaner than it was at the same time a year earlier is nearly three times greater (from an average of $13 \%$ of households in the control group to $13+21=34 \%$ in the treatment group, columns 3 and 4). Again, these reported levels are not driven by social-desirability bias: when asked whether the water they have access to now tastes good, treatment households are not more likely to say yes than treatment in the control group. This should be expected since all households have access to the same water - the only difference between them is how far that water is from them.

In addition to this higher level of satisfaction with water-related issues, Table 9 also shows that the BSI program, more generally, improved households' perceived quality of life. While only $23 \%$ of respondents in the control group report that the life of their household has improved compared to a year ago, this rises by 21 percentage points (almost a 100\% increase) in the treatment group (columns 7 and 8). Likewise, respondents in the treatment group are 28 percentage points more likely to report that their own life has improved (columns 9 and 10). When asked to score their satisfaction level with their life on a scale from 0 to 10 , respondents in the treatment group were 6 percentage points more likely to give a score of 5 or above, off a 69\% base in the control group. We also asked respondents how often they felt sad, worried, etc. over the past 7 days. We see a positive impact on mental health when we estimate the impact on a summary index composed of all three measures, but the effect is not significant (columns 13 and 14).

\section{Revealed Preferences: Long-run Demand for Household Connection}

The survey data analyzed so far suggests important leisure and subjective well-being gains for households in the treatment group. These gains came at a substantial financial cost to the households. Were they happier despite having to pay, or did they start to default on their loans 
and water payments? In this section, we use revealed preferences to test for the welfare impact of the BSI credit offer for participating households. We perform two sets of analyses.

First, we look at BSI repayment rates among households in the treatment group, two years after they took on the BSI credit. Assuming that default on the loan has no cost other than disconnection from the water grid (which is a reasonable assumption since there are no credit bureaus in Morocco, and Amendis does not have the apparatus to take defaulters to court), households for whom the household connection is welfare-decreasing should default on their loan.

Second, we look at the long-run take-up of the BSI offer among households in the control group. Recall that the BSI credit was available to control households throughout the study period and afterwards, but control households had to apply on their own, without procedural assistance from the research team. Given the relatively high procedural costs, the take-up rate among control households was very low in the first 6 months (at only 10\%). Over time, however, control households could have observed or learned about the returns to taking up the connection from their counterparts in the treatment group. If the returns are high enough, control households should have been willing to pay the upfront procedural costs.

\subsection{BSI Credit Repayment Rates in the Treatment Group}

We obtained historical data on BSI loan repayment as well as water bill payments from Amendis in June 2010, more than two years after households in the treatment group had been encouraged to apply for a BSI connection.

BSI loan repayment rates were quite high, with $44 \%$ of treated households having repaid all their installments to date, and $28 \%$ of households owing less than $20 \%$ of their total due. Only $5 \%$ were delinquent on more than $50 \%$ of the total due to date, and none of the households had been disconnected from the grid, suggesting that none had completely defaulted yet as of June 2010. In addition, the water consumption data shows no downwards trend in usage, which suggests that households did not revert to using the public tap over time.

\subsection{Spillover effects: Adoption of Piped Water by Control Households}

Given the large positive impacts we observe on the well-being of households in the treatment group, a natural question is whether the experience of these households encouraged their 
neighbors or social contacts to also invest in a home water connection. By August 2009 (18 months after the awareness campaign had taken place among treatment households), the fraction of control households that had applied for a connection had risen to $27 \%$ (from $10 \%$ a year earlier), despite the fact that they did not benefit from personalized assistance with their application. They could have learned from their neighbors about the benefit of being connected. To test whether the rise in connection rates among the control group over time can be attributed to social diffusion effects, we exploit the random variation in the density of households sampled for the treatment. ${ }^{9}$

Specifically, using GIS coordinates, we compute, for each control household, the number of sampled households that live within a given radius, and the number and share of them who were sampled for the treatment. We then regress whether a control household bought a connection on these measures of "exposure" to treated neighbors. We control for the total number of neighbors sampled for the study within each radius, since that is not randomly assigned. This strategy (employed by Kremer and Miguel (2007) and Dupas (2010)) provides clean identification for social diffusion effects, which usually present difficult issues (Manski, 1993).

The results are presented in Table 10. They suggest important diffusion effects. Among control households that had at least one other study household within 20 meters of their house, holding the number of study households within that radius constant, we find that those who had at least one treatment household within 20 meters were 18 percentage points more likely to have bought a water connection by August 2009 than those who did not have any treatment households within 20 meters (column 3). This corresponds to a more than $100 \%$ increase, compared to the mean connection rate of $15 \%$ among those with no neighbor assigned to the treatment.

\footnotetext{
${ }^{9}$ All households in the control group received information about the credit program in January 2009 (as part of the "debriefing" session we held with all study participants as per the IRB requirements), including information on the various procedures required to apply for it. While the research team had obtained pre-approval from the local authorities for all households in the control group to be allowed to apply for the credit program, a number of red tape steps remained for households to perform on their own, including two visits to the local Amendis agency and one visit to the Amendis headquarters.
} 


\section{Conclusion}

This paper studies the impact of granting households in urban Morocco the option to purchase a private connection to the water system on credit. We find that the demand for a household connection is high, with $68 \%$ of households taking on a 3-, 5- or 7-year loan to get connected when they are targeted by a door-to-door information campaign and helped with the necessary paperwork. Only $10 \%$ of the households who were eligible for the same offer but did not receive tailored information and procedural assistance connected over the same period.

After six months, this investment turned out to have significant private returns. While it freed up a lot of time for household members, it did not generate increases in labor market participation and income, but it led to important improvements in quality of life and welfare. In particular, it increased reported happiness and social integration. While the private returns are high, the public health impacts seem low, if not nonexistent. In the study context, household connections do not reduce the incidence of waterborne diseases compared to the existing system of public taps. This lack of health effect suggests that investing public funding in expanding access to household connections might not be justified from a public finance standpoint. However, the high private returns and high observed willingness to pay suggests that relaxing credit constraints for poor households and making credit access straightforward and transparent might be sufficient to generate important private investments in water connections.

These findings thus have some relevance for the debate on whether investment in water infrastructure should focus on providing safe shared drinking water sources, or whether providing individual access is important. Most experts conclude that it is not cost effective to individually connect all households to water. ${ }^{10}$ Previous studies (Ashraf et al., 2010; Kremer et al., 2010) have found very low willingness to pay for water purity, either in money (purchase of chlorine) or time (walking to the improved source). Part of the public investments in improving drinking water quality may be thus be lost if households are left to walk the "last mile", because they may simply not walk it (in our setting, all the public sources of water are clean, but in the Kremer et al., 2010 study, where only some sources were improved, few households appeared to

\footnotetext{
${ }^{10}$ However, some, like the NGO Gram Vikas in India, have the opposite point of view, and take it that it is essential for every household to have its own tap as well as sanitation facilities.
} 
switch source for most of their water needs). Our results, which reveal an important willingness to pay for access to water, suggest that offering households the option to pay all or part of the marginal cost to be individually connected with easy, affordable credit, may actually be a way to increase the rate of returns to the public investment. 


\section{References}

Ashraf, Nava, James Berry, and Jesse M.Shapiro (2010). “Can Higher Prices Stimulate Product Use? Evidence from a Field Experiment in Zambia”. American Economic Review 100(5): 2383-2413.

Banerjee, Abhijit, Esther Duflo, Rachel Glennerster and Cynthia Kinnan (2010). “The Miracle of Microfinance ? Evidence from a Randomized Evaluation”, unpublished manuscript, MIT.

Cattaneo, Matias D., Sebastian Galiani, Paul J. Gertler, Sebastian Martinez, and Rocio Titiunik (2009). “Housing, Health, and Happiness.” American Economic Journal: Economic Policy, 1(1): 75-105.

Dupas, Pascaline (2010). "Short-run Subsidies and Long-run Adoption of New Health Products: Evidence from a Field Experiment”. Mimeo, UCLA.

Esrey, S.A., J.B. Potash, L. Roberts, and C. Shiff, "Effects of improved water supply and sanitation on ascariasis, diarrhea, dracunculiasis, hookworm infection, schistosomiasis, and trachoma”, Bulletin of the World Health Organization, 69(5), 1991, pp. 609-621.

Fewtrell, Lorna, and John M. Colford, "Water, Sanitation and Hygiene: Interventions and Diarrhea. A Systematic Review and Meta-analysis”, HNP Discussion Paper, World Bank, July 2004.

Galiani, Sebastien, Paul Gertler and Ernesto Schargrodsky (2005). "Water for life: The impact of the privatization of water supply on child mortality”. Journal of Political Economy, Volume 113, pp. 83-120.

Gamper-Rabindran, Shanti, Shakeeb Khan and Christopher Timmins (2010). "The Impact of Piped Water Provision on Infant Mortality in Brazil: A Quantile Panel Data Approach,” Journal of Development Economics 92(2): 188-200.

Kling, Jeffrey, Jeffrey Liebman and Lawrence Katz (2007). “Experimental Analysis of Neighborhood Effects”. Econometrica, 75 (1): 83-119.

Kremer, Michael and Edward Miguel (2007). “The Illusion of Sustainability.” Quarterly Journal of Economics 122 (3): 1007-1065.

Kremer, Michael, Jessica Leino, Edward Miguel and Alix Zwane (2010). “Spring Cleaning: Rural Water Impacts, Valuation and Institutions”, Quarterly Journal of Economics, forthcoming. 
Kremer, Michael, Edward Miguel, Sendil Mullainathan, Clair Null and Alix Zwaine (2009). "Coupons, promoters, and dispensers: impact evaluations to increase water treatment", unpublished manuscript.

Manski, Charles (1993). “Identification of Endogenous Social Effects: The Reflection Problem”. Review of Economic Studies, 60(3): 531-42.

Merrick, Thomas W. “The Effect of Piped Water on Early Childhood Mortality in Urban Brazil, 1970 to 1976”, Demography, 22(1), February 1985, pp. 1-24.

WHO/UNICEF (2005). Water for Life: Making it Happen. WHO/UNICEF Joint Monitoring Programme for Water Supply and Sanitation. WHO Press, Geneva, Switzerland. 

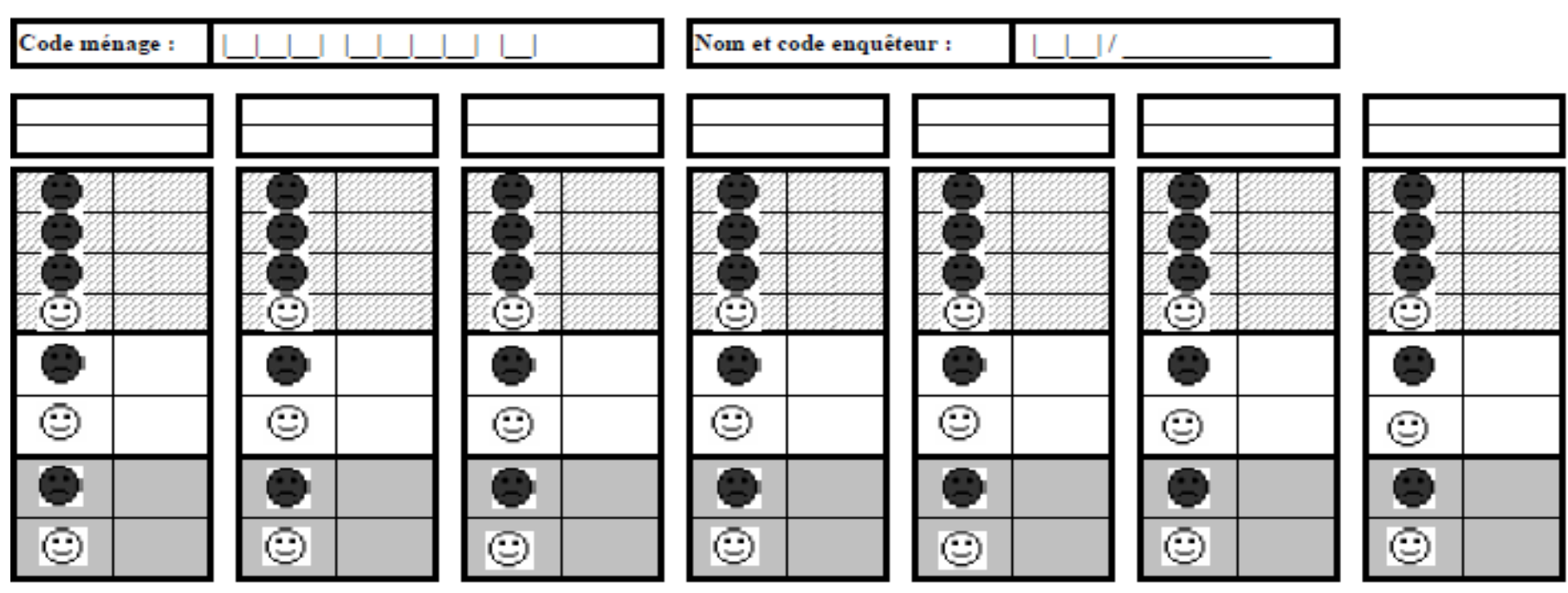

Rempli : Ménage $\square \quad$ Enquêteur $\square$

Figure 1. First Stage: Impact of the Encouragement Design

Panel A. Fraction of Households that Bought a Connection

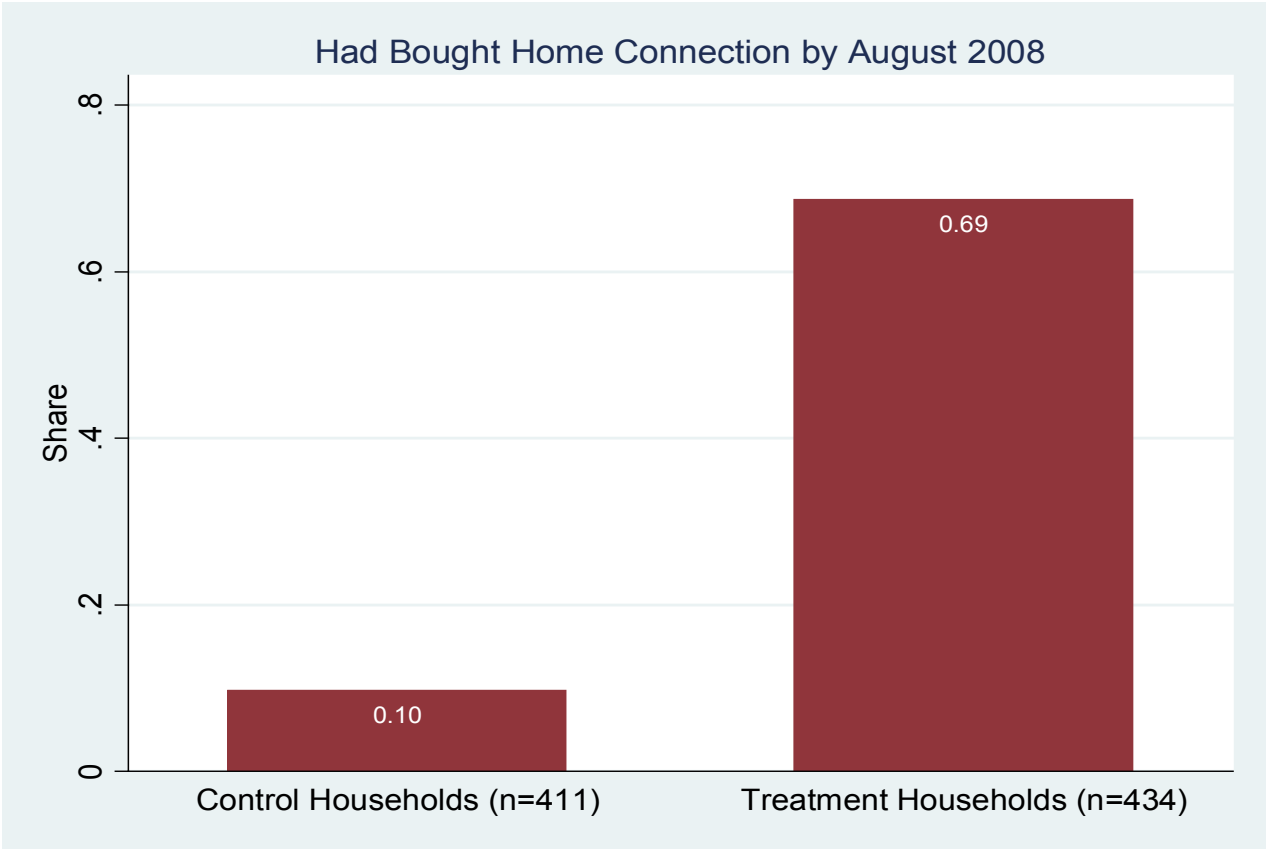

Panel B. Among Treatment Households: Take-up by Baseline Water Source

Share of Treatment Households who had Bought a Connection by August 2008 by Main Water Source at Baseline (August 2007)

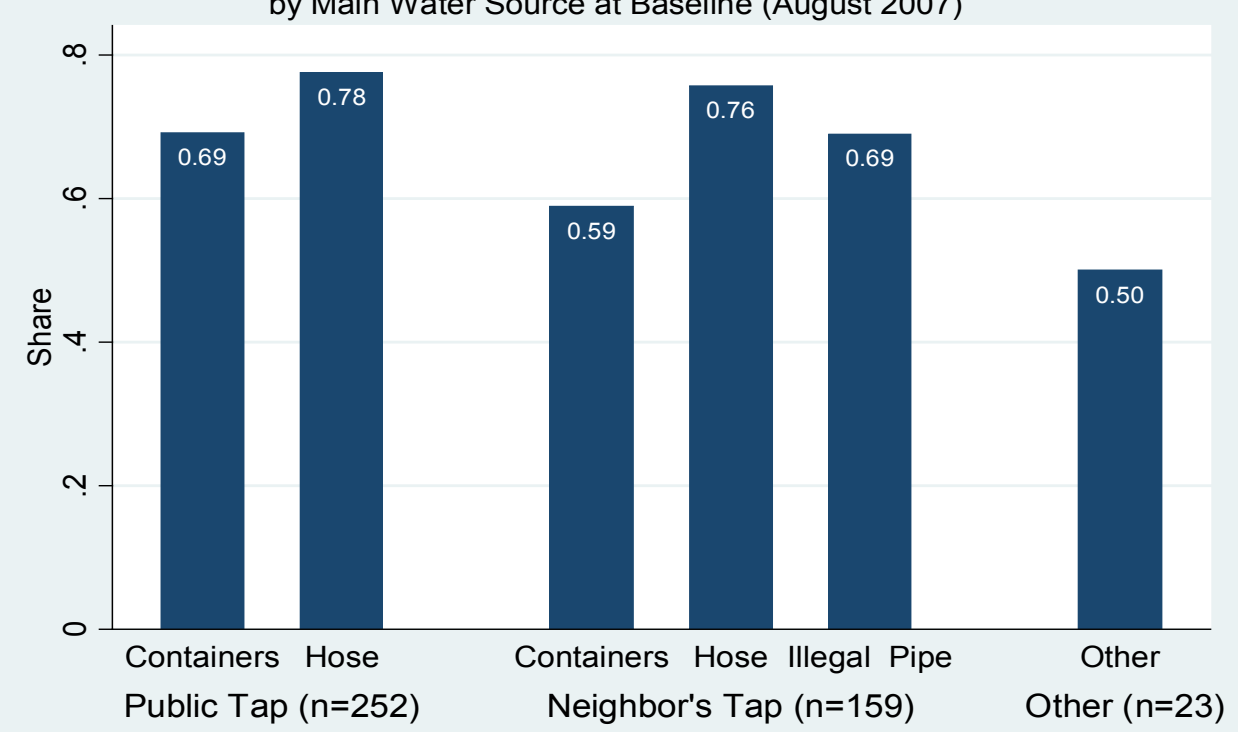

Notes: Data on connection status collected in August 2008. No household had a connection to the piped water system at baseline (August 2007). The encouragement intervention took place between February and April 2008. 


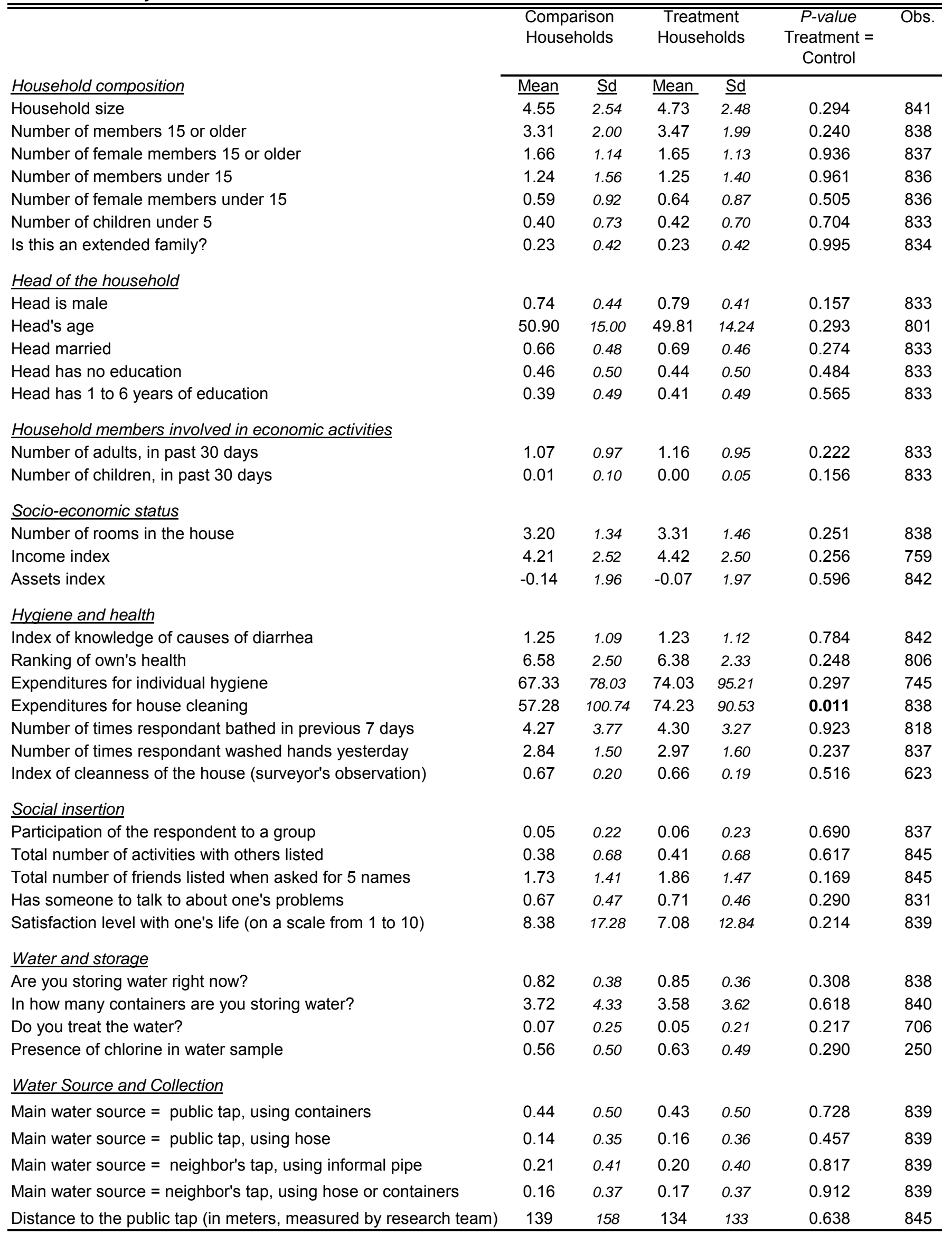

continued next page 


\begin{tabular}{|c|c|c|c|c|c|c|}
\hline \multirow[b]{2}{*}{ Time spent fetching water over the past 7 days (minutes) } & \multicolumn{2}{|c|}{$\begin{array}{l}\text { Comparison } \\
\text { Households }\end{array}$} & \multicolumn{2}{|c|}{$\begin{array}{l}\text { Treatment } \\
\text { Households }\end{array}$} & \multirow{2}{*}{$\begin{array}{c}\text { P-value } \\
\text { Treatment }= \\
\text { Control }\end{array}$} & \multirow{2}{*}{$\begin{array}{l}\text { Obs } \\
821\end{array}$} \\
\hline & 233 & 420 & 204 & 385 & & \\
\hline $\begin{array}{l}\text { Time spent in social activities while fetching water over the past } 7 \\
\text { days (minutes) }\end{array}$ & 8.2 & 44.1 & 7.6 & 37.9 & 0.845 & 822 \\
\hline \# of Containers filled with water over the past 7 days & 34.2 & 50.2 & 33.6 & 49.5 & 0.876 & 821 \\
\hline Payment made to get water over the past 7 days (dirhams) & 20.05 & 70.67 & 19.79 & 55.88 & 0.95 & 829 \\
\hline Number of times a child $(<15)$ fetched water in the past 3 days & 0.53 & 2.09 & 0.48 & 1.88 & 0.729 & 841 \\
\hline $\begin{array}{l}\text { Number of times a grown-up ( }>=15) \text { fetched water in the past } 3 \\
\text { days }\end{array}$ & 3.68 & 5.23 & 3.87 & 6.06 & 0.623 & 841 \\
\hline \multicolumn{7}{|l|}{ Households with main source of water = public tap, using containers } \\
\hline Distance to the public tap (in meters, measured by research team) & 106 & 167 & 118 & 127 & 0.481 & 346 \\
\hline Time spent fetching water over the past 7 days (minutes) & 445 & 533 & 421 & 492 & 0.675 & 328 \\
\hline $\begin{array}{l}\text { Time spent in social activities while fetching water over the past } 7 \\
\text { days (minutes) }\end{array}$ & 5.6 & 26.5 & 7.8 & 35.5 & 0.512 & 329 \\
\hline \# of Containers filled with water over the past 7 days & 52.6 & 48.3 & 51.9 & 47.1 & 0.894 & 328 \\
\hline Volume of water consumed over the past 7 days (liters) & 361 & 336 & 433 & 467 & 0.107 & 328 \\
\hline Payment made to get water over the past 7 days & 4.42 & 39.06 & 2.08 & 10.37 & 0.458 & 336 \\
\hline
\end{tabular}

Notes: Household averages collected during baseline survey (August 2007). 


\begin{tabular}{|c|c|c|c|c|c|c|c|c|c|c|c|c|}
\hline \multirow[b]{3}{*}{ Panel A. ITT Estimation } & \multirow{2}{*}{\multicolumn{2}{|c|}{$\begin{array}{l}(1) \quad(2) \\
\text { 1st Stage }\end{array}$}} & (3) & $(4)$ & (5) & (6) & $(7)$ & $(8)$ & (9) & (10) & $(11)$ & $(12)$ \\
\hline & & & \multicolumn{4}{|c|}{ Water Quality } & \multicolumn{6}{|c|}{ Water Quantity } \\
\hline & \multicolumn{2}{|c|}{ Connected } & \multicolumn{2}{|c|}{$\begin{array}{c}\text { Number of } E \text { Coli } \\
\text { detected in } \\
\text { drinking water }\end{array}$} & \multicolumn{2}{|c|}{$\begin{array}{l}\text { Chlorine detected in } \\
\text { drinking water }\end{array}$} & \multicolumn{2}{|c|}{$\begin{array}{l}\mathrm{HH} \text { reports having } \\
\text { enough water for } \\
\text { bathing }\end{array}$} & \multicolumn{2}{|c|}{$\begin{array}{l}\text { HH reports having } \\
\text { enough water for } \\
\text { cleaning }\end{array}$} & \multicolumn{2}{|c|}{$\begin{array}{l}\text { Number of baths o } \\
\text { showers taken by } \\
\text { respondent in the } \\
\text { past } 7 \text { days }\end{array}$} \\
\hline Treatment & $\begin{array}{c}0.60 \\
(0.03)^{\star \star \star}\end{array}$ & $\begin{array}{c}0.62 \\
(0.03)^{\star * *}\end{array}$ & $\begin{array}{c}2.80 \\
(3.00)\end{array}$ & $\begin{array}{c}2.56 \\
(3.44)\end{array}$ & $\begin{array}{c}0.15 \\
(0.06)^{* \star *}\end{array}$ & $\begin{array}{c}0.18 \\
(0.06)^{* \star *}\end{array}$ & $\begin{array}{c}0.20 \\
(0.03)^{* \star *}\end{array}$ & $\begin{array}{c}0.23 \\
(0.04)^{* * *}\end{array}$ & $\begin{array}{c}0.16 \\
(0.03)^{* * *}\end{array}$ & $\begin{array}{c}0.19 \\
(0.04)^{\star * *}\end{array}$ & $\begin{array}{c}0.30 \\
(0.16)^{*}\end{array}$ & $\begin{array}{c}0.25 \\
(0.16)\end{array}$ \\
\hline $\begin{array}{l}\text { Primary water source at baseline was an } \\
\text { informal pipe linked to neighbor's tap }\end{array}$ & & $\begin{array}{c}0.02 \\
(0.05)\end{array}$ & $\begin{array}{l}-2.03 \\
(3.76)\end{array}$ & $\begin{array}{l}-2.50 \\
(4.23)\end{array}$ & $\begin{array}{c}0.05 \\
(0.08)\end{array}$ & $\begin{array}{c}0.10 \\
(0.09)\end{array}$ & $\begin{array}{c}0.17 \\
(0.03)^{* * *}\end{array}$ & $\begin{array}{c}0.26 \\
(0.05)^{* * *}\end{array}$ & $\begin{array}{c}0.15 \\
(0.03)^{* * *}\end{array}$ & $\begin{array}{c}0.23 \\
(0.05)^{\star * *}\end{array}$ & $\begin{array}{l}-0.14 \\
(0.25)\end{array}$ & $\begin{array}{l}-0.27 \\
(0.29)\end{array}$ \\
\hline $\begin{array}{l}\text { Treatment } X \text { Informal pipe linked to } \\
\text { neighbor's tap }\end{array}$ & & $\begin{array}{l}-0.10 \\
(0.08)\end{array}$ & & $\begin{array}{c}1.11 \\
(7.00)\end{array}$ & & $\begin{array}{l}-0.13 \\
(0.14)\end{array}$ & & $\begin{array}{c}-0.18 \\
(0.05)^{\star * *}\end{array}$ & & $\begin{array}{c}-0.16 \\
(0.05)^{\star \star *}\end{array}$ & & $\begin{array}{c}0.25 \\
(0.45)\end{array}$ \\
\hline Household Controls & Yes & Yes & Yes & Yes & Yes & Yes & Yes & Yes & Yes & Yes & Yes & Yes \\
\hline Observations & 793 & 793 & 371 & 371 & 374 & 374 & 792 & 792 & 791 & 791 & 789 & 789 \\
\hline Mean in Control Group & 0.10 & 0.10 & 10.43 & 10.43 & 0.43 & 0.43 & 0.67 & 0.67 & 0.71 & 0.71 & 2.75 & 2.75 \\
\hline \multicolumn{13}{|c|}{ Panel B. Instrumental Variable Estimation: "Connected" Instrumented with "Treatment" } \\
\hline Connected & & & $\begin{array}{c}4.36 \\
(4.70)\end{array}$ & $\begin{array}{c}3.97 \\
(5.30)\end{array}$ & $\begin{array}{c}0.23 \\
(0.09)^{\star * *}\end{array}$ & $\begin{array}{c}0.27 \\
(0.09)^{\star * *}\end{array}$ & $\begin{array}{c}0.33 \\
(0.05)^{* * *}\end{array}$ & $\begin{array}{c}0.37 \\
(0.06)^{\star * *}\end{array}$ & $\begin{array}{c}0.27 \\
(0.05)^{* * *}\end{array}$ & $\begin{array}{c}0.31 \\
(0.06)^{\star * *}\end{array}$ & $\begin{array}{c}0.50 \\
(0.26)^{*}\end{array}$ & $\begin{array}{c}0.40 \\
(0.26)\end{array}$ \\
\hline $\begin{array}{l}\text { Primary water source at baseline was an } \\
\text { informal pipe linked to neighbor's tap }\end{array}$ & & & $\begin{array}{l}-2.23 \\
(3.82)\end{array}$ & $\begin{array}{l}-3.01 \\
(5.33)\end{array}$ & $\begin{array}{c}0.04 \\
(0.08)\end{array}$ & $\begin{array}{c}0.13 \\
(0.12)\end{array}$ & $\begin{array}{c}0.18 \\
(0.03)^{* * *}\end{array}$ & $\begin{array}{c}0.30 \\
(0.06)^{* * *}\end{array}$ & $\begin{array}{c}0.16 \\
(0.03)^{* * *}\end{array}$ & $\begin{array}{c}0.26 \\
(0.06)^{\star * *}\end{array}$ & $\begin{array}{l}-0.12 \\
(0.25)\end{array}$ & $\begin{array}{l}-0.35 \\
(0.36)\end{array}$ \\
\hline $\begin{array}{l}\text { Connected } X \text { Informal pipe linked to } \\
\text { neighbor's tap }\end{array}$ & & & & $\begin{array}{c}1.79 \\
(11.13)\end{array}$ & & $\begin{array}{l}-0.20 \\
(0.22)\end{array}$ & & $\begin{array}{c}-0.27 \\
(0.09)^{\star \star *}\end{array}$ & & $\begin{array}{c}-0.24 \\
(0.09)^{\star \star \star}\end{array}$ & & $\begin{array}{c}0.54 \\
(0.83)\end{array}$ \\
\hline Household Controls & & & Yes & Yes & Yes & Yes & Yes & Yes & Yes & Yes & Yes & Yes \\
\hline Observations & & & 371 & 371 & 374 & 374 & 792 & 792 & 791 & 791 & 789 & 789 \\
\hline
\end{tabular}

Notes: Data source: Endline survey conducted in August 2008. Clustered standard errors in parentheses. ***, ** * indicate significance at 1, 5 and 10\%.

Columns 3-6: Water quality tests were performed on a random subsample of participating households.

Household controls include: Number of children under 15 at baseline, quintile in asset distribution, quantity of water consumed the week before baseline, and distance to the public tap. 


(7)

(8)

(9)

(10)

Number of times a Number of times a

grown-up(>= 15)

child $(<15)$

Minutes Spent

by Household in past

y water $\begin{array}{cccc}\text { past } 3 \text { days } & \text { past } 3 \text { days } & \text { days } & \text { past } 3 \text { days }\end{array}$ year (dirhams)

expenditures

\section{Panel A. ITT Estimation}

$56 \quad-79$

$\begin{array}{cc}-0.69 & -0.91 \\ (0.23)^{* * *} & (0.29)^{* *}\end{array}$

$-66.56 \quad-79.59$

$-3.21 \quad-3.97$

$\begin{array}{cccc}(0.32)^{* * *} & (0.37)^{* * *} & (0.23)^{* * *} & (0.29)^{* * *} \\ -1.29 & -2.35 & -0.46 & -0.97\end{array}$

$(8.78)^{* * *}$
-30.75

$(10.49)^{\star * *}$

$(1.69)^{*}$

$(2.06)^{*}$

$411.79 \quad 443.65$

$-63.74$

$-4.13$

$-6.08$

$(42.55)^{\star * *}(50.36)^{\star * *}$

$-54.98$

$(61.23)^{\star *} \quad(51.21)$

$(51.21)$
-157.26

$(87.78)^{*}$

$68.60 \quad 66.03$

informal pipe linked to neighbor's tap

neighbor's tap

$$
(0.67)^{\star * *}
$$$$
0.95
$$

$(15.60)^{* * *}$

3.80

$(1.85)^{\star *}$

$(17.51)^{\star * \star}$

81.16

$(13.65)^{\star \star \star}$

$(0.67)^{\star * *} \quad(0.32)^{\star \star *}$

$\begin{array}{ccc}\text { Yes } & \text { Yes } & \text { Yes } \\ 787 & 787 & 455\end{array}$

Yes

Yes

$3.11 \quad 3.11$

455

455

0.86

793

Yes

793

\section{Yes}

793

81.92

4.13

\section{Yes}

793

4.13

Yes

Yes

$(38.37)^{\star *}$

74.65

Mean in Control Group

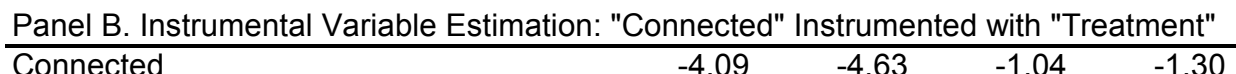

Connected

$(0.58)^{\star * *}$

$(0.33)^{\star * *}(0.41)^{\star \star *}$

$-110.81$

$-127.92$

$-5.34$

$\begin{array}{lll}(14.39)^{* * *} & (16.60)^{\star * *} & (2.78)^{*}\end{array}$

$-6.39$

-6.39
$(3.27)$

$(3.27)^{\star}$
-6.84

$(3.26)^{\star *}$

$(3.26)$
5.92

$(2.85)^{\star *}$

82.51

793

82.51

685.58

$(57.32)^{\star * *}$

713.60

$-111.73$

$(65.64)^{\star \star *}$

-44.42
$(48.66)$

$(53.08)^{\star *}$

(48.66)

$(48.66)$
-157.77

(134.00)

$(27.22)^{\star * *}$

neighbor's tap

$(1.21)^{\star *} \quad(0.47)^{\star \star \star}$

Household Controls

Observations

$\begin{array}{lllll}\text { Yes } & \text { Yes } & \text { Yes } & \text { Yes } & \text { Yes } \\ 787 & 787 & 455 & 455 & 793\end{array}$

455

455

793

Yes
793

Yes

Yes

Yes

Yes

793

$793 \quad 793$


Table 4. Impact on child health: Data from Illness Diaries (1 month each)

\begin{tabular}{|c|c|c|c|c|c|c|c|c|c|c|c|c|}
\hline \multirow{3}{*}{ Panel A. ITT Estimation } & $(1)$ & $(2)$ & (3) & $(4)$ & $(5)$ & $(6)$ & $(7)$ & $(8)$ & (9) & $(10)$ & $(11)$ & $(12)$ \\
\hline & \multicolumn{9}{|c|}{$\begin{array}{l}\text { Average Weekly Number of days with intense diarrhea }{ }^{\dagger} \text { : } \\
\text { Children } 0 \text { to } 7 \text { years old at baseline }\end{array}$} & \multirow{2}{*}{\multicolumn{3}{|c|}{$\begin{array}{l}\text { Average effect over three } \\
\text { follow-ups }\end{array}$}} \\
\hline & \multicolumn{3}{|c|}{$\begin{array}{l}\text { 1st follow-up: } \\
\text { May } 2008\end{array}$} & \multicolumn{3}{|c|}{$\begin{array}{l}\text { 2nd follow-up: } \\
\text { August } 2008\end{array}$} & \multicolumn{3}{|c|}{$\begin{array}{l}\text { 3rd follow-up: November } \\
\qquad 2008\end{array}$} & & & \\
\hline Treatment & $\begin{array}{c}0.05 \\
(0.07)\end{array}$ & $\begin{array}{c}0.05 \\
(0.09)\end{array}$ & $\begin{array}{c}0.02 \\
(0.08)\end{array}$ & $\begin{array}{l}-0.07 \\
(0.08)\end{array}$ & $\begin{array}{l}-0.07 \\
(0.09)\end{array}$ & $\begin{array}{l}-0.07 \\
(0.09)\end{array}$ & $\begin{array}{c}0.05 \\
(0.08)\end{array}$ & $\begin{array}{c}0.02 \\
(0.08)\end{array}$ & $\begin{array}{c}0.00 \\
(0.08)\end{array}$ & $\begin{array}{c}0.011 \\
(0.056)\end{array}$ & $\begin{array}{c}0.001 \\
(0.066)\end{array}$ & $\begin{array}{l}-0.014 \\
(0.066)\end{array}$ \\
\hline $\begin{array}{l}\text { Treatment } X \text { Informal pipe linked to } \\
\text { neighbor's tap }\end{array}$ & & $\begin{array}{l}-0.01 \\
(0.17)\end{array}$ & $\begin{array}{l}-0.01 \\
(0.17)\end{array}$ & & $\begin{array}{l}-0.01 \\
(0.19)\end{array}$ & $\begin{array}{l}-0.02 \\
(0.20)\end{array}$ & & $\begin{array}{c}0.14 \\
(0.22)\end{array}$ & $\begin{array}{c}0.14 \\
(0.22)\end{array}$ & & $\begin{array}{c}0.042 \\
(0.137)\end{array}$ & $\begin{array}{l}0.050 \\
(0.134)\end{array}$ \\
\hline Child Controls (age, gender) & Yes & Yes & Yes & Yes & Yes & Yes & Yes & Yes & Yes & Yes & Yes & Yes \\
\hline Household Controls & Yes & Yes & Yes & Yes & Yes & Yes & Yes & Yes & Yes & Yes & Yes & Yes \\
\hline \multicolumn{3}{|c|}{ Control for \# of Intense Diarrhea days observed in baseline diary } & Yes & & & Yes & & & Yes & & & Yes \\
\hline Observations & 470 & 470 & 470 & 473 & 473 & 473 & 458 & 458 & 458 & 1401 & 1401 & 1401 \\
\hline Mean in Control Group & 0.249 & 0.249 & 0.249 & 0.259 & 0.259 & 0.259 & 0.253 & 0.253 & 0.253 & 0.254 & 0.254 & 0.254 \\
\hline \multicolumn{13}{|c|}{ Panel B. Instrumental Variable Estimation: "Connected" Instrumented with "Treatment" } \\
\hline Connected & $\begin{array}{c}0.08 \\
(0.12)\end{array}$ & $\begin{array}{c}0.08 \\
(0.13)\end{array}$ & $\begin{array}{c}0.03 \\
(0.12)\end{array}$ & $\begin{array}{l}-0.11 \\
(0.12)\end{array}$ & $\begin{array}{l}-0.11 \\
(0.14)\end{array}$ & $\begin{array}{c}-0.1 \\
(0.14)\end{array}$ & $\begin{array}{l}0.09 \\
(0.12)\end{array}$ & $\begin{array}{c}0.02 \\
(0.12)\end{array}$ & $\begin{array}{c}0.00 \\
(0.12)\end{array}$ & $\begin{array}{c}0.02 \\
(0.09)\end{array}$ & $\begin{array}{c}0.00 \\
(0.10)\end{array}$ & $\begin{array}{l}-0.02 \\
(0.10)\end{array}$ \\
\hline $\begin{array}{l}\text { Connected } X \text { Informal pipe linked to } \\
\text { neighbor's tap }\end{array}$ & & $\begin{array}{c}0.01 \\
(0.31)\end{array}$ & $\begin{array}{l}-0.01 \\
(0.31)\end{array}$ & & $\begin{array}{l}-0.05 \\
(0.35)\end{array}$ & $\begin{array}{l}-0.07 \\
(0.37)\end{array}$ & & $\begin{array}{c}0.28 \\
(0.39)\end{array}$ & $\begin{array}{c}0.26 \\
(0.40)\end{array}$ & & $\begin{array}{c}0.08 \\
(0.24)\end{array}$ & $\begin{array}{c}0.09 \\
(0.24)\end{array}$ \\
\hline Child Controls (age, gender) & Yes & Yes & Yes & Yes & Yes & Yes & Yes & Yes & Yes & Yes & Yes & Yes \\
\hline Household Controls & Yes & Yes & Yes & Yes & Yes & Yes & Yes & Yes & Yes & Yes & Yes & Yes \\
\hline \multicolumn{3}{|c|}{ Control for \# of Intense Diarrhea days observed in baseline diary } & Yes & & & Yes & & & Yes & & & Yes \\
\hline Observations & 470 & 470 & 470 & 473 & 473 & 473 & 458 & 458 & 458 & 458 & 458 & 458 \\
\hline
\end{tabular}

Notes: Data source: Illness Diaries collected at three points in time (May 2008, August 2008 and November 2008).

Clustered standard errors in parentheses. Household controls as in Table 2. All regressions also include a control for the number of days the diary was properly filled and a dummy for "Informal pipe linked to neighbor's tap".

${ }^{\dagger}$ Intense diarrhea defined as follows: at least three loose stools within 24 hours 


(7)

(8)

(9)

(10)

Compared to last year, do you have less/as much as/more time to ...

\begin{tabular}{|c|c|c|c|c|c|c|c|c|c|c|c|c|}
\hline \multirow{2}{*}{$\frac{\text { Panel A. ITT Estimation }}{\text { Treatment }}$} & \multicolumn{2}{|c|}{.. do housework? } & \multicolumn{2}{|c|}{...watch tv? } & \multicolumn{2}{|c|}{...visit your family? } & \multicolumn{2}{|c|}{$\begin{array}{l}\text {...visit friends/ } \\
\text { neighbors? }\end{array}$} & \multicolumn{2}{|c|}{$\begin{array}{l}\text {...receive the visit } \\
\text { of your family? }\end{array}$} & \multicolumn{2}{|c|}{$\begin{array}{l}\text {...receive the visit } \\
\text { of friends/ } \\
\text { neighbors }\end{array}$} \\
\hline & $\begin{array}{c}0.11 \\
(0.046)^{\star *}\end{array}$ & $\begin{array}{c}0.14 \\
(0.053)^{\star *}\end{array}$ & $\begin{array}{c}0.16 \\
(0.044)^{\star * *}\end{array}$ & $\begin{array}{c}0.20 \\
(0.048)^{\star * *}\end{array}$ & $\begin{array}{c}0.13 \\
(0.043)^{\star * *}\end{array}$ & $\begin{array}{c}0.12 \\
(0.049)^{\star *}\end{array}$ & $\begin{array}{c}0.07 \\
(0.034)^{\star *}\end{array}$ & $\begin{array}{c}0.06 \\
(0.04)\end{array}$ & $\begin{array}{c}0.09 \\
(0.041)^{\star *}\end{array}$ & $\begin{array}{c}0.05 \\
(0.05)\end{array}$ & $\begin{array}{c}0.02 \\
(0.03)\end{array}$ & $\begin{array}{l}-0.03 \\
(0.04)\end{array}$ \\
\hline $\begin{array}{l}\text { Treatment } X \text { Informal pipe } \\
\text { linked to neighbor's tap }\end{array}$ & & $\begin{array}{l}-0.12 \\
(0.10)\end{array}$ & & $\begin{array}{c}-0.21 \\
(0.107)^{* *}\end{array}$ & & $\begin{array}{c}0.05 \\
(0.11)\end{array}$ & & $\begin{array}{c}0.07 \\
(0.09)\end{array}$ & & $\begin{array}{c}0.20 \\
(0.106)^{*}\end{array}$ & & $\begin{array}{c}0.24 \\
(0.078)^{\star * \star}\end{array}$ \\
\hline Household Controls & Yes & Yes & Yes & Yes & Yes & Yes & Yes & Yes & Yes & Yes & Yes & Yes \\
\hline Observations & 791 & 791 & 785 & 785 & 790 & 790 & 790 & 790 & 790 & 790 & 788 & 788 \\
\hline Mean in Control Group & -0.02 & -0.02 & -0.05 & -0.05 & -0.17 & -0.17 & -0.14 & -0.14 & -0.09 & -0.09 & -0.06 & -0.06 \\
\hline \multicolumn{13}{|c|}{ Panel B. Instrumental Variable Estimation: "Connected" Instrumented with "Treatment" } \\
\hline Connected & $\begin{array}{c}0.19 \\
(0.075)^{* *}\end{array}$ & $\begin{array}{c}0.22 \\
(0.084)^{\star \star \star}\end{array}$ & $\begin{array}{c}0.27 \\
(0.074)^{\star \star *}\end{array}$ & $\begin{array}{c}0.33 \\
(0.077)^{\star * *}\end{array}$ & $\begin{array}{c}0.21 \\
(0.072)^{\star * *}\end{array}$ & $\begin{array}{c}0.19 \\
(0.078)^{\star *}\end{array}$ & $\begin{array}{c}0.12 \\
(0.057)^{* *}\end{array}$ & $\begin{array}{c}0.10 \\
(0.06)\end{array}$ & $\begin{array}{c}0.00 \\
(0.068)^{* *}\end{array}$ & $\begin{array}{c}0.00 \\
(0.07)\end{array}$ & $\begin{array}{c}0.03 \\
(0.05)\end{array}$ & $\begin{array}{l}-0.05 \\
(0.06)\end{array}$ \\
\hline $\begin{array}{l}\text { Connected X Informal pipe } \\
\text { linked to neighbor's tap }\end{array}$ & & $\begin{array}{l}-0.18 \\
(0.17)\end{array}$ & & $\begin{array}{c}-0.34 \\
(0.197)^{\star}\end{array}$ & & $\begin{array}{c}0.13 \\
(0.20)\end{array}$ & & $\begin{array}{l}0.14 \\
(0.17)\end{array}$ & $\begin{array}{l}0.00 \\
0.00\end{array}$ & $\begin{array}{c}0.00 \\
(0.202)^{*}\end{array}$ & & $\begin{array}{c}0.44 \\
(0.151)^{* * *}\end{array}$ \\
\hline Household Controls & Yes & Yes & Yes & Yes & Yes & Yes & Yes & Yes & Yes & Yes & Yes & Yes \\
\hline Observations & 791 & 791 & 785 & 785 & 790 & 790 & 790 & 790 & 790 & 790 & 788 & 788 \\
\hline
\end{tabular}

Notes: Clutered standard errors in parentheses. ***, ** * indicate significance at 1, 5 and 10\%.

Answers to the questions were coded as follows: less time: -1 ; same time: 0 ; more time: +1

Household controls as in Table 2. All regressions include a dummy for "Informal pipe linked to neighbor's tap". 


$\begin{array}{lllllllll}(1) & (2) & (3) & (4) & (5) & (6) & (7) & (8) & (9)\end{array}$

Over the past 7 days, did you...

\begin{tabular}{|c|c|c|c|c|c|c|c|c|c|c|}
\hline \multirow{3}{*}{$\frac{\text { Panel A. ITT Estimation }}{\text { Treatment }}$} & & \multirow{2}{*}{\multicolumn{2}{|c|}{ 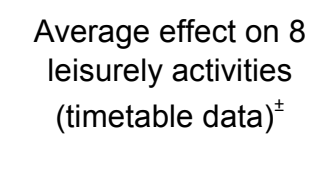 }} \\
\hline & \multicolumn{2}{|c|}{$\begin{array}{l}\text {...do housework at } \\
\text { least once a day? }\end{array}$} & \multicolumn{2}{|c|}{$\begin{array}{c}\text {...watch tv at least } \\
\text { once a day? }\end{array}$} & \multicolumn{2}{|c|}{$\begin{array}{c}\text {...visit family } \\
\text { members or } \\
\text { friends/neighbors at } \\
\text { least twice? }\end{array}$} & \multicolumn{2}{|c|}{$\begin{array}{c}\text {...receive the visit of } \\
\text { family members or } \\
\text { friends/neighbors at } \\
\text { least twice? }\end{array}$} & & \\
\hline & $\begin{array}{c}0.051 \\
(0.036)\end{array}$ & $\begin{array}{c}0.061 \\
(0.040)\end{array}$ & $\begin{array}{c}0.059 \\
(0.035)^{*}\end{array}$ & $\begin{array}{c}0.072 \\
(0.039)^{*}\end{array}$ & $\begin{array}{c}0.000 \\
(0.038)\end{array}$ & $\begin{array}{c}0.004 \\
(0.042)\end{array}$ & $\begin{array}{c}0.070 \\
(0.035)^{\star \star}\end{array}$ & $\begin{array}{c}0.031 \\
(0.039)\end{array}$ & $\begin{array}{c}0.170 \\
(0.047) * *\end{array}$ & $\begin{array}{c}0.158 \\
(0.054)^{* *}\end{array}$ \\
\hline $\begin{array}{l}\text { Treatment X Informal pipe } \\
\text { linked to neighbor's tap }\end{array}$ & & $\begin{array}{l}-0.048 \\
(0.084)\end{array}$ & & $\begin{array}{l}-0.060 \\
(0.083)\end{array}$ & & $\begin{array}{l}-0.020 \\
(0.095)\end{array}$ & & $\begin{array}{c}0.192 \\
(0.081)^{\star \star}\end{array}$ & & $\begin{array}{r}0.056 \\
(0.105)\end{array}$ \\
\hline Household Controls & Yes & Yes & Yes & Yes & Yes & Yes & Yes & Yes & Yes & Yes \\
\hline Observations & 790 & 790 & 788 & 788 & 791 & 791 & 789 & 789 & 788 & 788 \\
\hline Mean in Control Group & 0.59 & 0.59 & 0.43 & 0.43 & 0.32 & 0.32 & 0.19 & 0.19 & 1.33 & 1.33 \\
\hline
\end{tabular}

Panel B. Instrumental Variable Estimation: "Connected" Instrumented with "Treatment"

\begin{tabular}{|c|c|c|c|c|c|c|c|c|c|c|}
\hline Connected & $\begin{array}{c}0.086 \\
(0.059)\end{array}$ & $\begin{array}{c}0.098 \\
(0.065)\end{array}$ & $\begin{array}{c}0.099 \\
(0.058)^{*}\end{array}$ & $\begin{array}{c}0.115 \\
(0.064)^{*}\end{array}$ & $\begin{array}{l}-0.001 \\
(0.063)\end{array}$ & $\begin{array}{c}0.006 \\
(0.067)\end{array}$ & $\begin{array}{c}0.116 \\
(0.059)^{* *}\end{array}$ & $\begin{array}{c}0.050 \\
(0.063)\end{array}$ & $\begin{array}{c}0.281 \\
(0.080)\end{array}$ ** & $\begin{array}{c}0.253 \\
(0.088)\end{array}$ \\
\hline $\begin{array}{l}\text { Connected X Informal pipe } \\
\text { linked to neighbor's tap }\end{array}$ & & $\begin{array}{c}0.00 \\
(0.15)\end{array}$ & & $\begin{array}{l}-0.090 \\
(0.151)\end{array}$ & & $\begin{array}{l}-0.036 \\
(0.175)\end{array}$ & & $\begin{array}{c}0.371 \\
(0.161)^{* *}\end{array}$ & & $\begin{array}{r}0.150 \\
(0.197)\end{array}$ \\
\hline Household Controls & Yes & Yes & Yes & Yes & Yes & Yes & Yes & Yes & Yes & Yes \\
\hline Observations & 790 & 790 & 788 & 788 & 791 & 791 & 789 & 789 & 788 & 788 \\
\hline
\end{tabular}

Notes: Clustered standard errors in parentheses. ${ }^{\star \star \star},{ }^{* \star},{ }^{*}$ indicate significance at 1,5 and $10 \%$. Households controls as in Table 2 . All regressions include a dummy for "Informal pipe linked to neighbor's tap".

${ }^{ \pm}$Across 8 leisurely activites, average number of 30-min periods for which the respondent recalls performing activity. The 8 activities are: watching TV, exercising, being on the phone, going on a walk, praying, visiting other people, receiving other people at home, or "other leisure" (going to coffee shop, beach, etc.). 


\begin{tabular}{|c|c|c|c|c|c|c|c|c|c|c|c|c|}
\hline \multirow[b]{2}{*}{ Panel A. ITT Estimation } & $\overline{~(1) ~}$ & $\overline{(2)}$ & (3) & $(4)$ & (5) & (6) & (7) & (8) & (9) & $\overline{~(10) ~}$ & $\overline{~(11) ~}$ & $\overline{(12)}$ \\
\hline & \multicolumn{2}{|c|}{$\begin{array}{c}\text { Male Head had an } \\
\text { income generating } \\
\text { activity } \\
\text { in past } 30 \text { days }\end{array}$} & \multicolumn{2}{|c|}{$\begin{array}{l}\text { Female Head had } \\
\text { an income } \\
\text { generating activity } \\
\text { in past } 30 \text { days }\end{array}$} & \multicolumn{2}{|c|}{$\begin{array}{l}\text { A child age } 5-15 \text { (if } \\
\text { any) had an } \\
\text { income generating } \\
\text { activity } \\
\text { in past } 30 \text { days }\end{array}$} & \multicolumn{2}{|c|}{$\begin{array}{l}\text { Income generated } \\
\text { by Male Head } \\
\text { in past } 30 \text { days }\end{array}$} & \multicolumn{2}{|c|}{$\begin{array}{l}\text { Income generated } \\
\text { by Female Head } \\
\text { in past } 30 \text { days }\end{array}$} & \multicolumn{2}{|c|}{$\begin{array}{l}\text { Share of children } 5 \\
15 \text { (if any) who } \\
\text { completed the } \\
\text { school year }\end{array}$} \\
\hline Treatment & $\begin{array}{c}0.00 \\
(0.03)\end{array}$ & $\begin{array}{c}0.00 \\
(0.04)\end{array}$ & $\begin{array}{l}-0.03 \\
(0.02)\end{array}$ & $\begin{array}{c}-0.05 \\
(0.03)^{\star}\end{array}$ & $\begin{array}{l}-0.02 \\
(0.02)\end{array}$ & $\begin{array}{l}-0.02 \\
(0.02)\end{array}$ & $\begin{array}{c}9.1 \\
(67.5)\end{array}$ & $\begin{array}{c}34.0 \\
(74.1)\end{array}$ & $\begin{array}{l}-39.0 \\
(36.2)\end{array}$ & $\begin{array}{l}-55.8 \\
(42.6)\end{array}$ & $\begin{array}{l}-0.03 \\
(0.03)\end{array}$ & $\begin{array}{l}-0.02 \\
(0.04)\end{array}$ \\
\hline $\begin{array}{l}\text { Treatment } X \text { Informal pipe } \\
\text { linked to neighbor's tap }\end{array}$ & & $\begin{array}{l}-0.04 \\
(0.08)\end{array}$ & & $\begin{array}{c}0.09 \\
(0.06)\end{array}$ & & $\begin{array}{l}0.00 \\
(0.04)\end{array}$ & & $\begin{array}{l}-127.8 \\
(172.9)\end{array}$ & & $\begin{array}{c}83.7 \\
(79.2)\end{array}$ & & $\begin{array}{l}-0.01 \\
(0.07)\end{array}$ \\
\hline Household Controls & Yes & Yes & Yes & Yes & Yes & Yes & Yes & Yes & Yes & Yes & Yes & Yes \\
\hline Observations & 793 & 793 & 793 & 793 & 363 & 363 & 769 & 769 & 788 & 788 & 363 & 363 \\
\hline Mean in Control Group & 0.51 & 0.51 & 0.14 & 0.14 & 0.05 & 0.05 & 710.8 & 710.8 & 160.1 & 160.1 & 0.88 & 0.88 \\
\hline \multicolumn{13}{|c|}{ Panel B. Instrumental Variable Estimation: "Connected" Instrumented with "Treatment" } \\
\hline Connected & $\begin{array}{l}0.000 \\
(0.06)\end{array}$ & $\begin{array}{l}0.010 \\
(0.06)\end{array}$ & $\begin{array}{r}-0.050 \\
(0.04)\end{array}$ & $\begin{array}{l}-0.080 \\
(0.05)^{\star}\end{array}$ & $\begin{array}{r}-0.030 \\
(0.03)\end{array}$ & $\begin{array}{l}-0.030 \\
(0.03)\end{array}$ & $\begin{array}{c}15.0 \\
(111.2)\end{array}$ & $\begin{array}{c}54.1 \\
(118.4)\end{array}$ & $\begin{array}{l}-64.6 \\
(60.1)\end{array}$ & $\begin{array}{l}-89.4 \\
(68.5)\end{array}$ & $\begin{array}{l}-0.040 \\
(0.05)\end{array}$ & $\begin{array}{l}-0.030 \\
(0.05)\end{array}$ \\
\hline $\begin{array}{l}\text { Connected X Informal pipe } \\
\text { linked to neighbor's tap }\end{array}$ & & $\begin{array}{l}-0.070 \\
(0.15)\end{array}$ & & $\begin{array}{l}0.150 \\
(0.10)\end{array}$ & & $\begin{array}{l}-0.010 \\
(0.06)\end{array}$ & & $\begin{array}{l}-223.5 \\
(308.9)\end{array}$ & & $\begin{array}{c}139.4 \\
(141.3)\end{array}$ & & $\begin{array}{l}-0.020 \\
(0.11)\end{array}$ \\
\hline Household Controls & Yes & Yes & Yes & Yes & Yes & Yes & Yes & Yes & Yes & Yes & Yes & Yes \\
\hline Observations & 793 & 793 & 793 & 793 & 363 & 363 & 769 & 769 & 788 & 788 & 363 & 363 \\
\hline
\end{tabular}

dummy for "Informal pipe linked to neighbor's tap". 


\begin{tabular}{|c|c|c|c|c|c|c|c|c|c|c|c|c|}
\hline \multirow[b]{3}{*}{ Panel A. ITT Estimation } & (1) & (2) & (3) & $(4)$ & (5) & (6) & (7) & $(8)$ & $(9)$ & $(10)$ & $(11)$ & $(12)$ \\
\hline & \multirow{2}{*}{\multicolumn{2}{|c|}{$\begin{array}{l}\text { Do you belong to } \\
\text { a social group or } \\
\text { association? }\end{array}$}} & \multicolumn{10}{|c|}{ The respondent is in conflict or disagreement with: } \\
\hline & & & $\begin{array}{r}\text { People } \\
\text { his/her f } \\
\text { water } n\end{array}$ & $\begin{array}{l}\text { e from } \\
\text { amily on } \\
\text { natters }\end{array}$ & \multicolumn{2}{|c|}{$\begin{array}{c}\text { People from } \\
\text { his/her family on } \\
\text { property matters }\end{array}$} & \multicolumn{2}{|c|}{$\begin{array}{c}\text { People from } \\
\text { his/her family on } \\
\text { heritage matters }\end{array}$} & \multicolumn{2}{|c|}{$\begin{array}{l}\text { Neighbors on } \\
\text { water matters }\end{array}$} & \multicolumn{2}{|c|}{$\begin{array}{l}\text { Neighbors on } \\
\text { property matters }\end{array}$} \\
\hline \multirow[t]{2}{*}{ Treatment } & 0.02 & 0.03 & -0.11 & -0.12 & -0.01 & -0.01 & -0.03 & -0.03 & -0.08 & -0.09 & 0.01 & 0.01 \\
\hline & $(0.01)^{*}$ & $(0.01)^{\star *}$ & $(0.02)^{* * *}$ & $(0.03)^{\star \star *}$ & $(0.02)$ & $(0.02)$ & $(0.02)$ & $(0.03)$ & $(0.02)^{\star * \star}$ & $(0.03)^{* * *}$ & $(0.01)$ & $(0.01)$ \\
\hline $\begin{array}{l}\text { Treatment } X \text { Informal pipe } \\
\text { linked to neighbor's tap }\end{array}$ & & -0.03 & & 0.05 & & 0.00 & & 0.01 & & 0.03 & & 0.01 \\
\hline Household Controls & Yes & Yes & Yes & Yes & Yes & Yes & Yes & Yes & Yes & Yes & Yes & Yes \\
\hline Observations & 791 & 791 & 792 & 792 & 792 & 792 & 792 & 792 & 789 & 789 & 791 & 791 \\
\hline Mean in Control Group & 0.02 & 0.02 & 0.16 & 0.16 & 0.06 & 0.06 & 0.10 & 0.10 & 0.12 & 0.12 & 0.01 & 0.01 \\
\hline \multicolumn{13}{|c|}{ Panel B. Instrumental Variable Estimation: "Connected" Instrumented with "Treatment" } \\
\hline Connected & 0.04 & 0.04 & -0.18 & -0.19 & -0.02 & -0.02 & -0.04 & -0.05 & -0.13 & -0.14 & 0.02 & 0.02 \\
\hline Connected X Informal pipe & & -0.05 & & 0.06 & & 0.00 & & 0.01 & & 0.03 & & 0.03 \\
\hline linked to neighbor's tap & & $(0.05)$ & & $(0.08)$ & & $(0.05)$ & & $(0.07)$ & & $(0.07)$ & & $(0.04)$ \\
\hline Household Controls & Yes & Yes & Yes & Yes & Yes & Yes & Yes & Yes & Yes & Yes & Yes & Yes \\
\hline Observations & 791 & 791 & 792 & 792 & 792 & 792 & 792 & 792 & 789 & 789 & 791 & 791 \\
\hline
\end{tabular}

"Informal pipe linked to neighbor's tap". 


\begin{tabular}{|c|c|c|c|c|c|c|c|c|c|c|c|c|c|c|}
\hline \multirow{4}{*}{$\begin{array}{l}\text { Panel A. ITT Estimation } \\
\text { Treatment }\end{array}$} & (1) & (2) & (3) & (4) & (5) & (6) & (7) & (8) & (9) & (10) & (11) & (12) & (13) & (14) \\
\hline & \multicolumn{2}{|c|}{$\begin{array}{l}\text { Respondent } \\
\text { mentions water as } \\
\text { major source of } \\
\text { concern }\end{array}$} & \multicolumn{2}{|c|}{$\begin{array}{l}\text { Home is cleaner } \\
\text { than a year ago }\end{array}$} & \multicolumn{2}{|c|}{$\begin{array}{l}\text { Water tastes } \\
\text { good }\end{array}$} & \multicolumn{2}{|c|}{$\begin{array}{c}\text { Overall, the life of } \\
\text { the household has } \\
\text { improved compared } \\
\text { to a year ago }\end{array}$} & \multicolumn{2}{|c|}{$\begin{array}{l}\text { Overall, the } \\
\text { respondent's life } \\
\text { has improved } \\
\text { compared to a year } \\
\text { ago }\end{array}$} & \multicolumn{2}{|c|}{$\begin{array}{l}\text { Respondent rates } \\
\text { life satisfaction } \\
\text { level } \geq 5 \text { (on } 0-10 \\
\text { scale) }\end{array}$} & \multicolumn{2}{|c|}{$\begin{array}{l}\text { Average effect on } \\
\text { mental well-being }\end{array}$} \\
\hline & -0.38 & -0.43 & 0.21 & 0.20 & 0.00 & 0.00 & 0.21 & 0.21 & 0.28 & 0.27 & 0.06 & 0.08 & 0.034 & 0.022 \\
\hline & $(0.04)^{* * *}$ & $(0.04)^{\star * *}$ & $(0.03)^{* * *}$ & $(0.04)^{\star * *}$ & $(0.02)$ & $(0.02)$ & $(0.04)^{* * *}$ & $(0.04)^{\star * *}$ & $(0.03)^{* * *}$ & $(0.04)^{* * *}$ & $(0.03)$ & $(0.04)^{*}$ & $(0.025)$ & $(0.028)$ \\
\hline Treatment $X$ Informal pipe & & 0.22 & & 0.03 & & 0.03 & & 0.01 & & 0.04 & & -0.10 & & 0.057 \\
\hline linked to neighbor's tap & & $(0.08)^{\star * *}$ & & $(0.07)$ & & $(0.05)$ & & $(0.09)$ & & $(0.09)$ & & $(0.07)$ & & $(0.060)$ \\
\hline $\mathrm{HH}$ controls & Yes & Yes & Yes & Yes & Yes & Yes & Yes & Yes & Yes & Yes & Yes & Yes & Yes & Yes \\
\hline Observations & 792 & 792 & 792 & 792 & 791 & 791 & 792 & 792 & 792 & 792 & 793 & 793 & 788 & 788 \\
\hline Mean in Control Group & 0.66 & 0.66 & 0.13 & 0.13 & 0.57 & 0.57 & 0.23 & 0.23 & 0.24 & 0.24 & 0.69 & 0.69 & 0.60 & 0.60 \\
\hline \multicolumn{15}{|c|}{ Panel B. Instrumental Variable Estimation: "Connected" Instrumented with "Treatment" } \\
\hline Connected & $\begin{array}{c}-0.64 \\
(0.05)^{* * *}\end{array}$ & $\begin{array}{c}-0.69 \\
(0.05)^{\star \star *}\end{array}$ & $\begin{array}{c}0.34 \\
(0.05)^{\star * *}\end{array}$ & $\begin{array}{c}0.32 \\
(0.05)^{* * *}\end{array}$ & $\begin{array}{c}0.00 \\
(0.03)\end{array}$ & $\begin{array}{l}-0.01 \\
(0.03)\end{array}$ & $\begin{array}{c}0.35 \\
(0.06)^{\star \star *}\end{array}$ & $\begin{array}{c}0.34 \\
(0.06)^{\star * *}\end{array}$ & $\begin{array}{c}0.46 \\
(0.05)^{\star * *}\end{array}$ & $\begin{array}{c}0.43 \\
(0.06)^{\star * *}\end{array}$ & $\begin{array}{c}0.09 \\
(0.06)^{*}\end{array}$ & $\begin{array}{c}0.12 \\
(0.06)^{*}\end{array}$ & $\begin{array}{c}0.055 \\
(0.041)\end{array}$ & $\begin{array}{c}0.035 \\
(0.044)\end{array}$ \\
\hline $\begin{array}{c}\text { Connected X Informal pipe } \\
\text { linked to neighbor's tap }\end{array}$ & & $\begin{array}{c}0.29 \\
(0.14)^{\star *}\end{array}$ & & $\begin{array}{c}0.13 \\
(0.12)\end{array}$ & & $\begin{array}{l}0.06 \\
(0.10)\end{array}$ & & $\begin{array}{c}0.09 \\
(0.16)\end{array}$ & & $\begin{array}{c}0.16 \\
(0.16)\end{array}$ & & $\begin{array}{l}-0.16 \\
(0.13)\end{array}$ & & $\begin{array}{c}0.115 \\
(0.110)\end{array}$ \\
\hline $\mathrm{HH}$ controls & Yes & Yes & Yes & Yes & Yes & Yes & Yes & Yes & Yes & Yes & Yes & Yes & Yes & Yes \\
\hline Observations & 792 & 792 & 792 & 792 & 791 & 791 & 792 & 792 & 792 & 792 & 793 & 793 & 788 & 788 \\
\hline
\end{tabular}

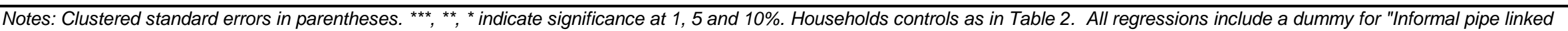
to neighbor's tap".

\pm Average effect over three measures (over past 7 days, respondent felt, more often than not, sad / worried / satisfied). Coded so that 1 reflects high well-being and 0 reflects low well-being. 
Table 10: Social Diffusion: Adoption of Water Connection by Control Households

\begin{tabular}{|c|c|c|c|c|c|c|c|c|}
\hline & $(1)$ & $(2)$ & $(3)$ & $(4)$ & $(5)$ & $(6)$ & \multirow{2}{*}{\multicolumn{2}{|c|}{$\begin{array}{l}\text { sample mean } \\
\text { [std. dev.] } \\
\text { of indep. var. }\end{array}$}} \\
\hline & \multicolumn{6}{|c|}{ Dep. Var: Bought BSI Connection } & & \\
\hline & \multicolumn{3}{|c|}{$\begin{array}{c}\text { Among those with at least one } \\
\text { sampled household within Radius } \\
\text { R=20 meters }\end{array}$} & \multicolumn{3}{|c|}{$\begin{array}{c}\text { Among those with at least one } \\
\text { sampled household within Radius } \\
\text { R=50 meters }\end{array}$} & $R=20$ & $R=50$ \\
\hline \multirow[t]{2}{*}{ At least one household assigned to treatment within radius $R$} & 0.176 & & & 0.078 & & & 0.10 & 0.05 \\
\hline & $(0.076)^{* *}$ & & & $(0.054)$ & & & {$[.15]$} & {$[.16]$} \\
\hline \multirow[t]{2}{*}{ Share of households assigned to treatment within radius $R$} & & 0.148 & & & 0.113 & & 0.08 & 0.05 \\
\hline & & $(0.082)^{*}$ & & & $(0.067)^{*}$ & & {$[.15]$} & {$[.16]$} \\
\hline \multirow[t]{2}{*}{ \# of households assigned to treatment within radius $R$} & & & 0.108 & & & 0.017 & 0.10 & 0.05 \\
\hline & & & $(0.046)^{\star *}$ & & & $(0.020)$ & {$[.15]$} & {$[.16]$} \\
\hline \multirow[t]{2}{*}{ Total \# of households sampled for study within radius $\mathrm{R}$} & 0.04 & 0.055 & 0.006 & 0.019 & 0.022 & 0.014 & 1.91 & 3.94 \\
\hline & $(0.030)$ & $(0.028)^{*}$ & $(0.035)$ & $(0.010)^{*}$ & $(0.010)^{\star *}$ & $(0.015)$ & [1.48] & [3.01] \\
\hline Observations & 221 & 221 & 221 & 345 & 345 & 345 & & \\
\hline $\begin{array}{l}\text { Mean of Dep. Var. among those with no household } \\
\text { assigned to treatment within radius } R\end{array}$ & 0.15 & 0.15 & 0.15 & 0.16 & 0.16 & 0.16 & & \\
\hline
\end{tabular}

Notes: For each radius choice, sample restricted to households with at least one sampled household within the chosen radius. Clustered standard errors in parentheses. ${ }^{\star}$ significant at $10 \%$; ** significant at 5\%; *** significant at $1 \%$. 
Table A1. Correlates of Home Connection Take-up (among Treatment Group)

Dummy for Zone 2 Price (6640 MAD)

Bought a Home

Connection

Dummy for Zone 3 Price (9370 MAD)

$-0.091$

(0.082)

Number of households living on the plot

0.043

(0.116)

$-0.015$

$(0.028)$

Main water source $=$ public tap

0.087

$(0.052)^{*}$

Log (Distance to the closest public tap)

0.046

$(0.027)^{*}$

Total number of water fetching trips in the past 3 days

0.001

(0.004)

Share of water fetching trips in the past 3 days done by child ( $<15$ years)

0.184

Household Size

$(0.075)^{\star \star *}$

0.026

$(0.010)^{* *}$

0.048

Asset index

$(0.011)^{* * *}$

Number of adults with an income-generating activity

0.041

$(0.023)^{*}$

Household Head is Male

0.022

(0.056)

Latitude

2.000

(2.085)

Longitude

$-1.075$

(1.250)

Observations

430

R-Squared

0.13

Mean of Dev. Var.

0.687

Notes: Sample restricted to households randomly assigned to the treatment group. Coefficient estimated through OLS regression. Omitted price category is Zone 1 (3790 MAD).

Robust standard errors in parentheses, clustered at the cluster level.

* significant at 10\%; ** significant at 5\%; *** significant at $1 \%$. 